\title{
Parallelisms between sea surface temperature changes in the western tropical Atlantic (Guiana Basin) and high latitude climate signals over the last 140000 years
}

\author{
O. Rama-Corredor ${ }^{1}$, B. Martrat ${ }^{1}$, J. O. Grimalt ${ }^{1}$, G. E. López-Otalvaro ${ }^{2}$, J. A. Flores ${ }^{2}$, and F. Sierro ${ }^{2}$ \\ ${ }^{1}$ Department of Environmental Chemistry, IDAEA-CSIC, Jordi Girona 18, 08034 Barcelona, Catalonia, Spain \\ ${ }^{2}$ Department of Geology, University of Salamanca, Plaza de la Merced s/n, 37008 Salamanca, Spain
}

Correspondence to: J. O. Grimalt (joan.grimalt@idaea.csic.es)

Received: 31 January 2015 - Published in Clim. Past Discuss.: 2 April 2015

Accepted: 2 September 2015 - Published: 6 October 2015

Abstract. Sea surface temperatures (SST) in the Guiana Basin over the last $140 \mathrm{ka}$ were obtained by measuring the $\mathrm{C}_{37}$ alkenone unsaturation index $\mathrm{U}_{37}^{k^{\prime}}$ in the sediment core MD03-2616 $\left(7^{\circ} \mathrm{N}, 53^{\circ} \mathrm{W}\right)$. The resulting data set is unique in the western tropical Atlantic region for this period. The SSTs range from 25.1 to $28.9^{\circ} \mathrm{C}$, i.e. glacial-interglacial amplitude of $3.8^{\circ} \mathrm{C}$, which is in the range of change of other tropical areas.

During the last two interglacial stages (marine isotope stages; MIS1 and MIS5e) and warm long interstadials (MIS5d-a), a rapid transmission of climate variability from Arctic-tropical latitudes is recorded. During these periods, the MD03-2616 SSTs show a conspicuous parallelism with temperature changes observed in Greenland and SST records of North Atlantic mid-latitude cores (Iberian Margin $38^{\circ} \mathrm{N}$, Martrat et al., 2007).

The last deglaciation in the Guiana Basin is particularly revealing. MIS2 stands out as the coldest period of the interval analysed. The events recorded in Guiana parallel northern latitude events such as the Bølling-Allerød warming and the Younger Dryas cooling which ensued. These oscillations were previously documented in the $\delta^{18} \mathrm{O}$ of the Sajama tropical ice core (Bolivia) and are present in Guiana, with rates of ca. $6^{\circ} \mathrm{C} \mathrm{ka}^{-1}$ and changes of over $2{ }^{\circ} \mathrm{C}$.

During the glacial interval, significant abrupt variability is observed, e.g. oscillations of $0.5-1.2^{\circ} \mathrm{C}$ during MIS3, which is about $30 \%$ of the maximum glacial-interglacial SST change. In the MD03-2616 record, it is possible to unambiguously identify either the Dansgaard-Oeschger oscillations described in northern latitudes or the SST drops associ- ated with the Heinrich events characteristic of North Atlantic records. Although these events form the background of the climate variability observed, what truly shapes SSTs in the Guiana Basin is a long-term tropical response to precessional changes, which is modulated in the opposite way to Northern Hemisphere variability. This lack of synchrony is consistent with other tropical records in locations to the north or south of the Guiana Basin and evidences an Arctic-tropical decoupling when a substantial reduction in the Atlantic meridional overturning circulation (AMOC) takes place.

\section{Introduction}

Abrupt climate changes have been recorded in a variety of environmental sensors and archives. Examples of these are (i) isotopic composition of foraminifera (Bond et al., 1993; Lisiecki and Raymo, 2005; McManus et al., 1994; Peterson et al., 2000; Shackleton et al., 2000), sea surface temperatures (SSTs) derived from alkenones (Herbert and Schuffert, 2000; Martrat et al., 2004, 2014) or $\mathrm{Mg} / \mathrm{Ca}$ measured in marine sediments (Cacho et al., 2006; Marino et al., 2013; Martinez-Mendez et al., 2010); (ii) isotopic composition of speleothems (Cheng et al., 2009; Wang et al., 2001); and (iii) isotopes and greenhouse gases trapped in continental polar and tropical ice (Loulerge et al., 2008; EPICA, 2004; North Greenland Ice Core Project members, 2004; Jouzel et al., 2007; Wolff et al., 2010; Thompson et al., 1998). Diverse locations across both hemispheres, from Greenland and the North Atlantic through South America and Antarctica, among others, record these abrupt climate changes. The At- 
lantic has experienced changes from warm to cold conditions and vice-versa in sub-millennial timescale events (Barker et al., 2011, 2015) which punctuated the orbital-driven glacialinterglacial evolution (Berger, 1978; Jouzel et al., 2007).

Variability in the Atlantic meridional overturning circulation (AMOC) has been identified as one of the primary causes of these abrupt climate variations (Ganopolski and Rahmstorf, 2001, Gherardi et al., 2009; Hendy et al., 2002). In the past, AMOC reductions brought about a decrease in the transfer of heat to northern latitudes, with climate switching from warm to cold stadial modes and the consequent extension of continental and sea ice (Lippold et al., 2012; Robinson et al., 2005); while freshwater input into the North Atlantic due to melting of North American lakes may have contributed to the onset of some of these episodes (Broecker and Hemming, 2003; Teller et al., 2002) as well as changes in the amount of salt reaching the North Atlantic as a result of variations in leakage from the Indian Ocean (Knorr and Lohmann, 2003; Weijer et al., 2002). Additionally, modulation of bipolar see-saw mechanisms leading to North Atlantic deep water formation, either from Arctic or Antarctic sources, may also have an influence on overall AMOC variability (Knorr and Lohmann, 2003; Knutti et al., 2004; Lippold et al., 2012; Martrat et al., 2007; McManus et al., 2004; Ritz et al., 2013; Stocker, 1998; Stocker and Marchal, 2000; Stocker and Johnsen, 2003; Weaver et al., 2003).

These processes draw on scenarios in which abrupt climate variability responds to changes occurring at polar latitudes, whether northern or southern. Most of the evidence to explain Atlantic climate processes has been obtained from sediment cores located at mid-high latitudes (Allen et al., 1999; Bond et al., 1993; Martrat et al., 2007; McManus et al., 2004; Shackleton et al., 2000). However, several aspects of these changes are as yet to be explored, among them, the occurrence of abrupt climate transitions in tropical latitudes. Climate changes in tropical Atlantic regions have received less attention, particularly those encompassing variability beyond the last deglaciation, e.g. Dubois et al. (2014), Herbert and Schuffert (2000), Jaeschke et al. (2007), Keigwin and Boyle (1999), and Schmidt et al. (2004). The study of these low-latitude regions may provide information on (i) the influence of high climate variability in these areas, (ii) specific local processes that may generate rapid changes, (iii) mechanisms of polar-to-tropical transmission of abrupt climate variability and their influence at low latitudes and (iv) the significance of tropical atmospheric/oceanic reorganisations in sustaining abrupt climate variability (Seager and Battisti, 2007). These questions need to be addressed because the tropics are the main global stores of heat and salt. They may have played an active role in the development of abrupt climate variability or, at least, may have contributed to these processes at several stages.

The Guiana Basin hydrography is modulated by the water discharges of the Amazon River and oscillations of the intertropical convergence zone (ITCZ). These oscillations

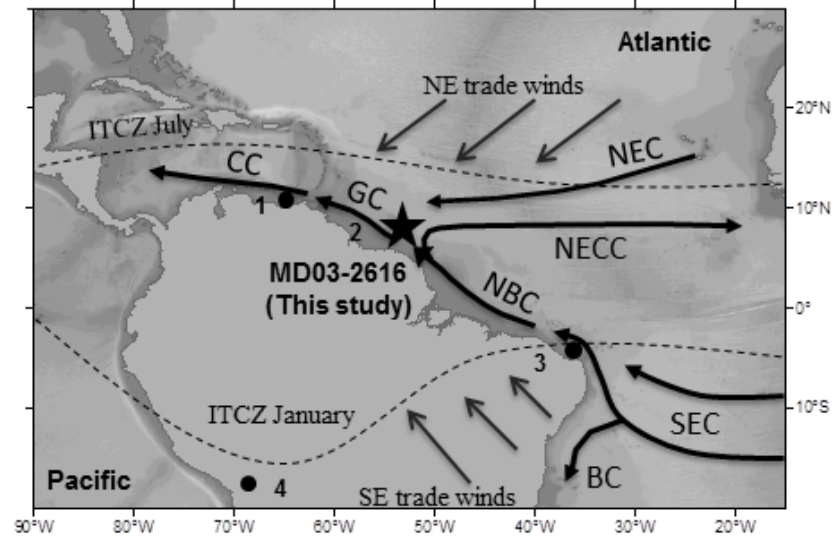

Figure 1. Map showing the sites mentioned in the text: (1) ODP 1002 (Peterson et al., 2000), (2) MD03-2616, this study $\left(7.4875^{\circ} \mathrm{N}, 53.0080^{\circ} \mathrm{W} ;-1233\right.$ metres below sea level), (3) GeoB3910 (Jaeschke et al., 2007, (4) Sajama ice core; Thompson et al., 1998). Guiana current (GC), north equatorial current (NEC), Caribbean current (CC), north Brazil current (NBC), north equatorial countercurrent (NECC), south equatorial current (SEC) and Brazil current (BC). ITCZ and trade winds are shown (humid northeasterlies when the ITCZ moves north of the equator and dry southeasterlies when it moves southward).

modify winds and ocean currents, and eventually salinity, river run-off, and nutrient supply (Figs. 1 and S1 in the Supplement). This area is therefore located in a cornerstone site that records the impact of several main processes of potential influence on the climate of the planet during the glacial and interglacial periods, including capacity of initiation and development of rapid climate changes. In turn, changes in this tropical region could also bear an influence on Arctic regions. Given that the Guiana current (GC) is part of the wider system transporting high saline waters from the Indian Ocean to the Caribbean Sea, changes in its intensity may lead to an accumulation of salt in the tropical North Atlantic. These accumulation processes may ultimately modify the density of high-latitude surface waters and the North Atlantic climate because of their influence on thermohaline circulation (Schmidt et al., 2004; Ritz et al., 2013).

Alkenones synthesised by haptophyte algae have been used as a proxy for reconstructing SSTs, particularly in the Atlantic Ocean (Müller et al., 1998; Jaeschke et al., 2007; Martrat et al., 2007). The $\mathrm{U}_{37}^{k^{\prime}}$ alkenone unsaturation index is used here to estimate the SSTs (Brassell et al., 1986; Müller et al., 1998) during the past $140 \mathrm{ka}$ in the western tropical Atlantic. These SST variations trace abrupt climate events and may help to identify connections with northern or southern Atlantic processes and to evaluate the sensitivity of tropical areas to the changes occurring at high latitudes. 


\section{Regional settings}

Core MD03-2616 was recovered in Guiana Basin $\left(7.4875^{\circ} \mathrm{N}, 53.0080^{\circ} \mathrm{W}\right)$, located about $650 \mathrm{~km}$ off the coast and at $1233 \mathrm{~m}$ below sea level during the PICASSO cruise on board the R/V Marion Dufresne (Fig. 1). The core has a total length of $39 \mathrm{~m}$. Most of the sediment is composed of olive green clay, and is rich in foraminifera and organic matter, with little bioturbation (Shipboard Scientific Party, 2003).

\subsection{Atmospheric circulation}

The Guiana Basin (Fig. 1) is directly influenced by the latitudinal migration of the ITCZ between $10^{\circ} \mathrm{N}$ and $5^{\circ} \mathrm{S}$ (MullerKarger et al., 1989). Seasonal movements of the ITCZ generate two rainy periods (boreal late spring - early summer and winter) and two periods with less rain (boreal late summer - early autumn and early spring). This spatial and seasonal variability in the ascending branch of the Hadley cell has an impact on the vegetation and hydrology of the area. Trade winds change their direction depending on the ITCZ position (Fig. 1). South-east trade winds prevail when the ITCZ is in its northern position (drier continental climate; short rainfall events in Guiana). Conversely, there is an opposite flow of north-east trade winds when the ITCZ is in its southern position (wetter oceanic climate; long rainfall events in Guiana).

\subsection{Oceanographic setting}

According to the Levitus database (Levitus, 1982), the present average annual SST at the MD03-2616 location is $27.6^{\circ} \mathrm{C}$ and the average annual salinity is $33.6 \mathrm{psu}$ (Reynolds et al., 2002, Fig. S1). The GC washes the coastline from south-east to north-west (Fig. 1) and pushes the Amazon River plume towards the Caribbean Sea (Masson and Delecluse, 2001; Muller-Karger et al., 1988, 1995). This current extends from the north Brazil current (NBC), which branches off from the south equatorial current (SEC, Peterson and Stramma, 1991). The NBC provides salty, warm waters to the western tropical Atlantic north of the equator (Stramma and Schott, 1999). When the ITCZ is in its northern position the NBC undergoes a retroflection, generating the north equatorial countercurrent (NECC) and decreasing the GC flow. The formation and strengthening of the NBC retroflection diverts part of the Amazon plume from the Caribbean Sea towards the Central Atlantic (Rühlemann et al., 2001; Zabel et al., 2003), thereby decreasing the sediment supply to the MD03-2616 site. This decrease is compensated by the north equatorial current (NEC) that flows southward in West Africa and crosses the Atlantic westward (Arnault, 1987) to supply the Guiana and Caribbean currents (Bourlès et al., 1999, Fig. 1). Antarctic Intermediate Water (AAIW) originates from subpolar latitudes around Antarctica and flows at $400-1000 \mathrm{~m}$ depth with a pressure range of 600

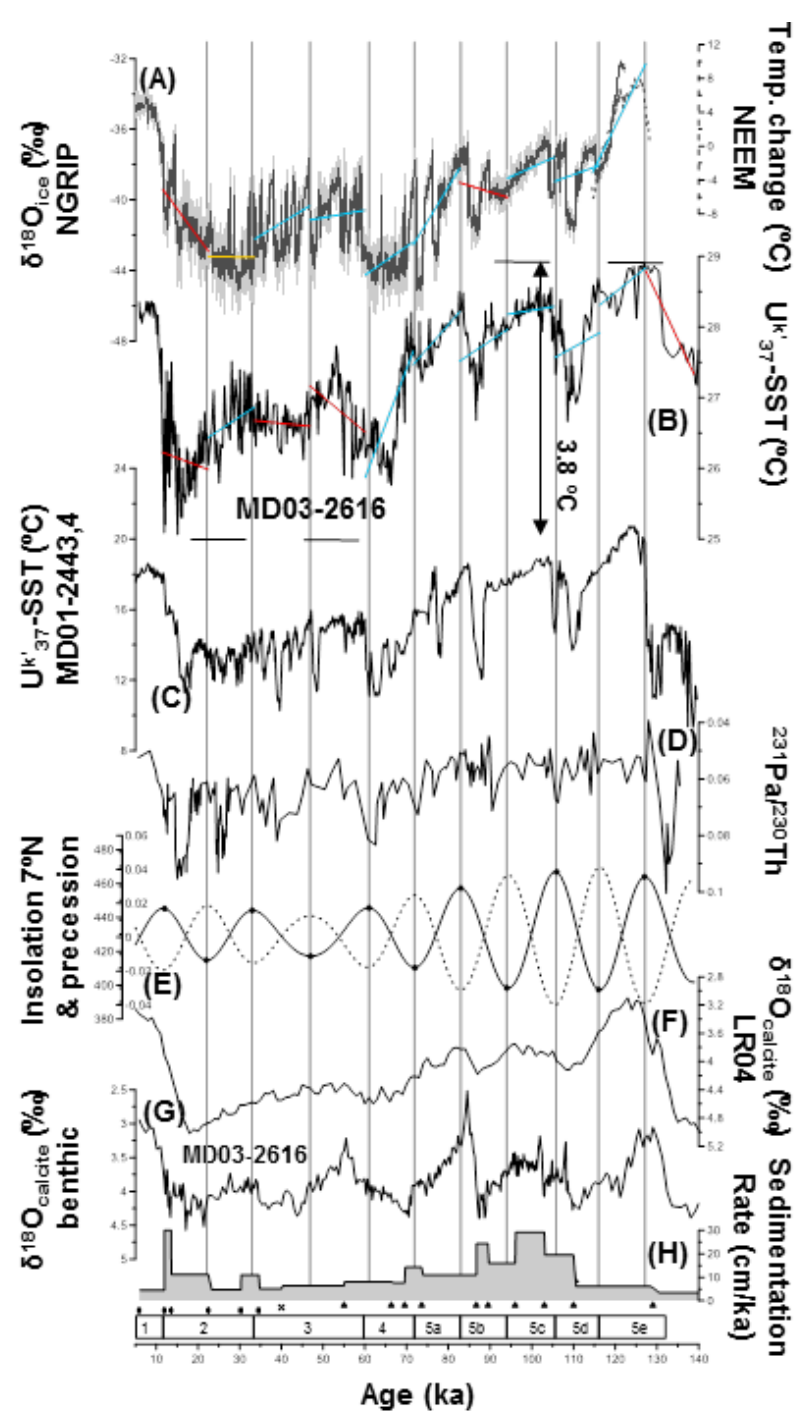

Figure 2. Guiana SSTs vs. Greenland and orbital changes. (a) $\delta^{18} \mathrm{O}_{\text {ice }}(\%$ ) NGRIP (GICC05 modelext timescale; Wolff et al., 2010; Svensson et al., 2011) and temperature change in NEEM (dashed line; NEEM community members, 2013), (b) MD03-2616 $\mathrm{U}_{37}^{k^{\prime}}$-SST (this study). (c) MD01-2443,4 U $\mathrm{U}_{37}^{k^{\prime}}$-SST (Martrat et al., 2007), (d) ${ }^{231} \mathrm{~Pa} /{ }^{230} \mathrm{Th}$ composite (Bohm et al., 2015, McManus et al., 2004), (e) precessional changes (dashed line), which are inversely related to the daily insolation at $7^{\circ} \mathrm{N}$ (solid line) during the summer solstice (Berger, 1978). Circles mark maximum and minimum of insolation at $7^{\circ} \mathrm{N}$. (f) LR04 stack (Lisiecki and Raymo, 2005). (g) MD03-2616 $\delta^{18} \mathrm{O}_{\text {calcite }}$ benthic (López-Otálvaro et al., 2009), (h) sedimentation rate of MD03-2616 (this study). The control points used for the age model (Table 1) are shown: dots for AMS- ${ }^{14} \mathrm{C}$ dates, a cross for the $Y$ bioclimatic event, and triangles for tie points between MD03-2616 benthic isotopes (LópezOtálvaro et al., 2009) and the LR04 stack (Lisiecki and Raymo, 2005). The trends between the perihelion passage in the NH boreal summer (precession minima, insolation maxima) and winter solstices (precession maxima, insolation minima) are shown. 
$1050 \mathrm{dbar}$. It is identified in the tropical region by a salinity minimum, which contrasts with the upper North Atlantic deep water that flows at a deeper depth $1200-4000 \mathrm{~m}$ and has an assigned higher pressure of 1200-2050 dbar (Stramma and Schott, 1999; Lankhorst et al., 2009).

\subsection{River's run-off}

The Amazon is the main river in South America. Its annual mean flow of $200000 \mathrm{~m}^{3} \mathrm{~s}^{-1}$ contributes $6 \times 10^{12} \mathrm{~m}^{3} \mathrm{yr}^{-1}$ of fresh water to the tropical Atlantic (Muller-Karger et al., 1988). Guiana's rivers, Maroni and Oyapock, have discharges of 1600 and $800 \mathrm{~m}^{3} \mathrm{~s}^{-1}$, respectively (Masson and Delecluse, 2001). All of them are directly influenced by the ITCZ, involving maximum run-off when the ITCZ is in its southern position. The Amazon River plume is rich in nutrients and suspended sediments, and forms coastal mud banks. The terrigenous material, which accumulates on the continental shelf, is transported to the Guiana Basin by the GC in a continuous wide band of $100-150 \mathrm{~km}$. The GC carries much of the Amazon River plume northward to the Caribbean Sea (Muller-Karger et al., 1995). These river waters have a high sediment load and are rich in organic compounds generated in the Amazon forests (Saliot et al., 2001). The Amazon River is also a major contributor of nutrients to the marine system, which provides appropriate habitats for plankton growth, including haptophyte algae (López-Otálvaro et al., 2009).

\section{Methods}

\subsection{Lipids and SSTs}

Sediment samples $(2.5 \mathrm{~g})$ from MD03-2616 were taken every $3 \mathrm{~cm}$. The method of analysis of organic compounds, including $\mathrm{C}_{37}$ alkenones, is described in detail in Villanueva et al. (1997). Samples were freeze-dried and n-nonadecan1-ol, n-hexatriacontane and n-dotetracontane were added as internal standards. The organic matter was then extracted with dichloromethane in an ultrasonic bath. The extracts were saponified with $10 \% \mathrm{KOH}$ in methanol to eliminate interfering compounds such as fatty acids, ester waxes, amino acids, and proteins. The neutral lipid phase was recovered from this alkaline digestion with hexane, which was evaporated to near-dryness under a gentle $\mathrm{N}_{2}$ stream. The lipid mixture was redissolved with toluene, derivatised with bis(trimethylsilyl)trifluoroacetamide and analysed by gas chromatography coupled to flame ionisation detection (GC-FID).

Instrumental analyses were performed with a Varian 3400 equipped with a CPSIL-5 CB column coated with $100 \%$ dimethylsiloxane (film thickness $0.12 \mu \mathrm{m}$ ). Hydrogen was the carrier gas $\left(50 \mathrm{~cm} \mathrm{~s}^{-1}\right)$. The oven was programmed from 90 to $170^{\circ} \mathrm{C}$ at $20^{\circ} \mathrm{C} \mathrm{min}^{-1}$, then to $280^{\circ} \mathrm{C}$ at $6^{\circ} \mathrm{C} \mathrm{min}-1$ (holding time $35 \mathrm{~min}$ ), to $300^{\circ} \mathrm{C}$ at $10^{\circ} \mathrm{C} \mathrm{min}^{-1}$ (holding time $7 \mathrm{~min}$ ) and finally to $320^{\circ} \mathrm{C}$ at $10{ }^{\circ} \mathrm{C} \mathrm{min}^{-1}$ (holding time $3 \mathrm{~min}$ ). The injector was programmed from $90^{\circ} \mathrm{C}$ (holding time $0.3 \mathrm{~s}$ ) to $320^{\circ} \mathrm{C}$ at $200^{\circ} \mathrm{C} \mathrm{min}^{-1}$. The detector was maintained at $320^{\circ} \mathrm{C}$.

Selected samples were analysed by gas chromatography coupled with mass spectrometry (GC-MS; Thermo DSQ II Instruments). The instrument was equipped with a CPSIL-5 $\mathrm{CB}$ column and $\mathrm{He}$ was used as the carrier gas. The injection conditions were the same as described above for GC-FID. Mass spectra were acquired in the electron impact mode (70 $\mathrm{eV})$ scanning from 50 to 700 mass units in cycles of $1 \mathrm{~s}$.

The $\mathrm{U}_{37}^{k^{\prime}}$ index was obtained from the concentrations of $\mathrm{C}_{37}$ alkenones, $\mathrm{C}_{37: 2} /\left(\mathrm{C}_{37: 2}+\mathrm{C}_{37: 3}\right)\left[\mathrm{C}_{37: 3}\right.$ refers to heptatriaconta-8E,15E,22E-trien-2-one and $\mathrm{C}_{37: 2}$ to heptatriaconta-15E,22E-dien-2-one], and used to calculate the SST $\left[\mathrm{U}_{37}^{k^{\prime}}=0.033 \times \mathrm{SST}+0.044\right.$; Müller et al., 1998, $\pm 0.5^{\circ} \mathrm{C}$; Villanueva and Grimalt, 1997 ; Grimalt et al., 2001]

\section{Age model and sedimentation rates}

The age model was based on linear interpolations between 18 age pointers (Table 1). Between 5.9 and $34.5 \mathrm{ka}$ the pointers encompassed six $\mathrm{AMS}^{14} \mathrm{C}$ dates measured in tests of planktonic foraminifera Globigerinoides sacculifer. They were calibrated to calendar years with the Calib 7.0 software and Marine 13 curve (Reimer et al., 2013). The assigned reservoir age was 284 years and delta $R=-15 \pm 37$. Both of them were obtained from the Marine Reservoir Correction database (http://calib.qub.ac.uk/marine/) as a mean of the closest points in the area. One radiocarbon measurement $(148 \mathrm{~cm}, 26.8 \mathrm{ka})$ was identified as a reversal and excluded. This reversal was detected by comparison of the previously published MD03-2616 benthic $\delta^{18} \mathrm{O}_{\text {calcite }}$ determined from Uvigerina peregrina tests (López-Otálvaro et al., 2009) with the age model of Stern and Lisiecki (2014) that records the age interval of Termination I in North Atlantic Intermediate Water at $16.8-18.3 \mathrm{ka}$.

The age model of the older sections was constructed comparing the MD03-2616 benthic $\delta^{18} \mathrm{O}_{\text {calcite }}$ with the LR04 benthic $\delta^{18} \mathrm{O}_{\text {calcite }}$ stack. This stack relies on a non-linear model of ice volume, which simulates the response of ice sheets to boreal summer insolation variations (Lisiecki and Raymo, 2005). One additional pointer used (40 ka) was the last occurrence of Pulleniatina obliquiloculata (Ericson and Wollin, 1956; Kennett and Huddlestun, 1972; Prell and Damuth, 1978; Vicalvi et al., 1999; Peterson et al., 2000; López-Otálvaro et al., 2009) known as biozone $Y$ transition (Table 1). The presence of $P$. obliquiloculata in the ocean Atlantic sediments is diachronous. The disappearance of this species occurred in the Gulf of Mexico at $60 \mathrm{ka} \mathrm{BP}$, in the Caribbean Sea at $50 \mathrm{ka}$ BP, and in the equatorial Atlantic at 35 ka BP (Prell and Damuth, 1978). In Vicalvi et al. (1999) it was indicated that the biohorizon $Y_{\text {P.Obliq }}$ was between 40 and $42 \mathrm{ka}$. López-Otálvaro et al. (2009) studied the bios- 
tratigraphy in this MD03-2616 core and used $40 \mathrm{ka}$. In the Amazon fan ODP942 core, the age of $40 \mathrm{ka}$ was also used as biohorizon of the area (Maslin et al., 2000). In the present study, we keep the same criterion as in Lopez-Otalvaro et al. (2009).

\section{Results}

\subsection{Sedimentation rates}

The age model was made using radiocarbon measurements, benthic $\delta^{18} \mathrm{O}_{\text {calcite }}$ (Fig. 2g) determined from Uvigerina peregrine and biozone events (Table 1). The sedimentation rates (SRs) over time in the Guiana Basin (Fig. 2h) are supposed to be influenced by the sediment yield from the Amazon River (Govin et al., 2014). The two interglacial periods studied have a low SR (marine isotope stages; MIS1 $3.5 \mathrm{~cm}^{2} \mathrm{ka}^{-1}$ and MIS5e $4.5 \mathrm{~cm}^{2} \mathrm{ka}^{-1}$, Fig. 2h). The MIS5 complex $(5 \mathrm{a}, 5 \mathrm{~b}, 5 \mathrm{c}, 5 \mathrm{~d})$ has a SR that is higher than $10 \mathrm{~cm}^{2} \mathrm{ka}^{-1}$, MIS5d being the period with the highest sedimentation $\left(29 \mathrm{~cm}^{2} \mathrm{ka}^{-1}\right)$. The glacial period started with a decrease in SR because in MIS4 and MIS3 much of the terrigenous sediment yield was deposited in the Amazon fan. Despite this decrease in SRs, the amount of sediment that arrived in these glacial periods was higher than that of the interglacial periods $\left(\sim 8 \mathrm{~cm}^{2} \mathrm{ka}^{-1}\right)$ most of the time. The SRs during glacials have a similar pattern to that of other cores from the region such as ODP942 (Maslin et al., 2012). The highest SR $\left(30 \mathrm{~cm}^{2} \mathrm{ka}^{-1}\right)$ corresponded to a deglaciation of the Andes with an increase of Amazon River run-off (Thompson et al., 1998, Maslin et al., 2012).

\subsection{SST glacial/interglacial patterns}

The SSTs of core MD03-2616 display a well-defined orbital modulation of glacial and interglacial reference MIS: the last interglacial complex MIS5e-a (from 127.3 to $71.6 \mathrm{ka} \mathrm{BP}$ ), the glacial stages from MIS4 to MIS2 (from 71.6 to $11.5 \mathrm{ka}$ $\mathrm{BP}$ ), and the present interglacial or MIS1 (from 11.5 to $0 \mathrm{ka}$ BP). The alkenone-derived SSTs range from a minimum of $25.1^{\circ} \mathrm{C}$ during MIS2 to a maximum of $28.9^{\circ} \mathrm{C}$ in MIS5e (Fig. 2b).

The alkenones found in all the samples of the present study correspond to distributions containing $\mathrm{C}_{37}$ methyl ketones, $\mathrm{C}_{38}$ methyl and ethyl ketones, $\mathrm{C}_{39}$ methyl and ethyl ketones, and $\mathrm{C}_{40}$ ethyl ketones. This distribution named as Type A in previous studies (Lopez and Grimalt, 2006; Grimalt and Lopez, 2007) is widely found in marine sediments and waters, and the correspondence between SST and $\mathrm{U}_{37}^{k^{\prime}}$ has not been observed to depend on salinity changes. Another distribution, Type B, is characterised by well-defined relationships between carbonyl position and chain parity, involving methyl and ethyl ketones for the odd and even carbon number homologs, respectively. This second distribution is found in sedimentary environments of salinities lower than seawa- ter (Lopez and Grimalt, 2006; Grimalt and Lopez, 2007) and it was not found in any of the samples of the present study. The lack of influence of salinity changes in the SST alkenone record is also consistent with a previous calcareous nanoplankton study performed in the same core (LópezOtálvaro et al., 2009) in which the species that could be dependent on salinity did not show any systematic correspondence to this parameter.

The glacial-interglacial SST amplitude, $3.8^{\circ} \mathrm{C}$, may appear small compared to those from higher latitudes, though it is in line with SSTs observed in other tropical areas such as southern China, $2.8^{\circ} \mathrm{C}\left(8^{\circ} \mathrm{N}\right.$; Pelejero et al., 1999), northeastern Brazil, $2.8^{\circ} \mathrm{C}\left(4^{\circ} \mathrm{S}\right.$; Jaeschke et al., 2007), and the eastern Pacific warm pool $\left(2.7,4.2\right.$ and $4^{\circ} \mathrm{C}$ at $7^{\circ} \mathrm{N}, 0^{\circ} \mathrm{N}$ and $1^{\circ} \mathrm{S}$, respectively; Dubois et al., 2014). Similarly to these previous studies, the MD03-2616 glacial-interglacial SST amplitude displays the highest SST difference observed in the interval studied, well above any other SST change associated with the rapid oscillations recorded. The top of the core contains MIS1 strata (latest dated sample at $5.9 \mathrm{ka} \mathrm{BP}$ ) and averages $28.3^{\circ} \mathrm{C}$, i.e. lower SSTs than during MIS5e (Fig. 2b). MIS 2 stands out as the coldest interval with minimum SST of $25.1^{\circ} \mathrm{C}$ and LGM average of $26.2^{\circ} \mathrm{C}\left(+0.6^{\circ} \mathrm{C}\right.$ warmer than those in the MARGO database for this area; Margo, 2009). Sub-stages MIS5d and MIS5b are identified from the decrease in SST to $26.7^{\circ} \mathrm{C}$. The SST in MIS4, $25.8^{\circ} \mathrm{C}$, was colder than in MIS3, $27.7^{\circ} \mathrm{C}$. The average SST during MIS3, $26.7^{\circ} \mathrm{C}$, was higher than in MIS2 and MIS4, i.e. 26.1 and $26.5^{\circ} \mathrm{C}$, respectively.

The SSTs of core MD03-2616 show a conspicuous parallelism with temperature changes observed in Greenland during the last two interglacials (MIS1 and MIS5e) and warm long interstadials (MIS5d-a). The trends (warming/cooling) between maximum and minimum precession in Guiana and Greenland are shown as follows (Fig. 2a-b): oscillations at warming intervals in red (in Guiana, MIS3 and late MIS2; in Greenland, MIS5b and late MIS2), changes at cooling intervals in blue (in Guiana, MIS5e-a, MIS4, and early MIS2; in Greenland, MIS5d-c, and from MIS5a to MIS3) and, finally, trends of less than $1 \%$ of the maximum change in yellow (in Greenland, late MIS3).

\subsection{Abrupt SST changes}

The samples analysed in core MD03-2616, $n=576$, provided an average resolution of 210 years. The resolution in the radiocarbon age period was also 210 years. Only in certain periods, 23.8-29.8 and 35.2-39.6, was the resolution closer to 400 years. Fig. S2 shows the SST record in which the sampled and analysed levels between 5 and $70 \mathrm{ka}$ are indicated. The time intervals corresponding to the Younger Dryas and the Heinrich events (HEs) are described by at least six measurements. The resolution of the HEs is as average comparable to other tropical cores such as those from the west Amazonia caves quoted in the study (Fig. $3 e$ and f). 
Table 1. Control points used for the age model in MD03-2616, assuming regular sediment accumulation rates between reference strata. Radiocarbon dating was carried out at the Poznan Radiocarbon Laboratory (Poz-code, Poznan, Poland) and dates were calibrated using Calib 7.0 software and the Marine13 curve (Reimer et al., 2013; reservoir age of 284 years and delta $R$ of $-15 \pm 37$; 1 sigma range; reservoir age and delta $R$ were obtained from the website http://calib.qub.ac.uk/marine/). Note that a reversal reported at $148 \mathrm{~cm}$ was not used in the age model, the Pulleniatina obliquiloculata disappearance is located at $288 \mathrm{~cm}$ (López-Otálvaro et al. 2009) and the LR04 benthic $\delta^{18} \mathrm{O}_{\mathrm{calcite}}$ stack (Lisiecki and Raymo, 2005) is used as a reference for the older sections.

\begin{tabular}{|c|c|c|c|c|}
\hline Depth $(\mathrm{cm})$ & Sample type & Radiocarbon age $(\mathrm{ka})$ or ref & Calibrated age (ka BP) & Error $(\mathrm{ka})$ \\
\hline 1 & $\begin{array}{l}\text { G. sacculifer } \\
\text { (Poz-22473) }\end{array}$ & $5.490 \pm 0.035$ & 5.898 & 0.066 \\
\hline 28 & $\begin{array}{l}\text { G. sacculifer } \\
\text { (Poz-22474) }\end{array}$ & $10.610 \pm 0.050$ & 11.940 & 0.127 \\
\hline 76 & $\begin{array}{l}\text { G. sacculifer } \\
\text { (Poz-22476) }\end{array}$ & $12.090 \pm 0.050$ & 13.548 & 0.088 \\
\hline 148 & $\begin{array}{l}\text { G. sacculifer } \\
\text { (Poz-22477) }\end{array}$ & $22.890 \pm 0.130$ & 26.821 & 0.212 \\
\hline 176 & $\begin{array}{l}\text { G. sacculifer } \\
\text { (Poz-22478) }\end{array}$ & $19.010 \pm 0.090$ & 22.477 & 0.097 \\
\hline 212 & $\begin{array}{l}\text { G. sacculifer } \\
\text { (Poz-22480) }\end{array}$ & $26.370 \pm 0.180$ & 30.249 & 0.298 \\
\hline 260 & $\begin{array}{l}\text { G. sacculifer } \\
\text { (Poz-22481) }\end{array}$ & $30.950 \pm 0.300$ & 34.500 & 0.271 \\
\hline 288 & P. obliquiloculata & $Y$ interval & 40.000 & 2.000 \\
\hline 384 & U. Peregrina & LR04 stack & 55.000 & 4.000 \\
\hline 474.5 & U. Peregrina & LR04 stack & 66.300 & 4.000 \\
\hline 499 & U. Peregrina & LR04 stack & 69.500 & 4.000 \\
\hline 557 & U. Peregrina & LR04 stack & 73.600 & 4.000 \\
\hline 701 & U. Peregrina & LR04 stack & 86.700 & 4.000 \\
\hline 769 & U. Peregrina & LR04 stack & 89.500 & 4.000 \\
\hline 873 & U. Peregrina & LR04 stack & 96.000 & 4.000 \\
\hline 1077 & U. Peregrina & LR04 stack & 103.000 & 4.000 \\
\hline 1213 & U. Peregrina & LR04 stack & 110.000 & 4.000 \\
\hline 1329 & U. Peregrina & LR04 stack & 129.000 & 4.000 \\
\hline
\end{tabular}

Previous studies identified abrupt changes based on the fastest rate of change associated with the last deglaciation (Martrat et al., 2004; Rahmstorf, 2003). In the Guiana record, this interval presents a rate of change of $+2^{\circ} \mathrm{C} \mathrm{ka}^{-1}\left(3.1^{\circ} \mathrm{C}\right.$ in 1550 years in the MD03-2616 record; Fig. 3c; Table 3). Thus, an abrupt event is defined as a warming/cooling change higher than $0.5^{\circ} \mathrm{C}$ and $2{ }^{\circ} \mathrm{C} \mathrm{ka}^{-1}$ which have more than three points in the event. Most events were found in the glacial period when instability was higher (Fig. 3b). Some relevant SST oscillations are detected at transitional phases such as MIS5d $\left(+2.0^{\circ} \mathrm{C}\right.$ ), MIS5b (up to $+3.5^{\circ} \mathrm{C}$ ), MIS4 $\left(-3.5^{\circ} \mathrm{C}\right)$, during early MIS3 $\left(+2.2^{\circ} \mathrm{C}\right)$, early MIS2 (e.g. +5.1 or $\left.-3.3^{\circ} \mathrm{C}\right)$ or around the Bølling-Allerød (B-A) and the Younger Dryas (YD) events in a North Atlantic context (Figs. 3b, 4b; Table 3).

The intra-MIS5e variability previously reported in the North Atlantic (Oppo et al., 2001, 2006) is also observed in the Guiana Basin (Fig. 4b). The SSTs followed a pace of events analogous to those of Greenland from MIS5c to MIS5a (Greenland stadial (GS) and Greenland interstadial (GI) from 25 to 19). Generally, the SST oscillations did not exceed $0.5^{\circ} \mathrm{C}$, though some exceptions were observed around GS-24 (cold event C23; McManus et al., 1994, 2002), GS-22 (cold event C21; McManus et al., 1994, 2002) and GS-25 (cold event C24; McManus et al., 1994, 2002). The transitions from MIS5a to MIS4 and from MIS3 to MIS2 were abrupt (e.g. cooling of $-1.5^{\circ} \mathrm{C}$ in $0.4 \mathrm{ka}$; Table 3 ) and presented high instability, i.e. warming and cooling events occurred rapidly (in less than $2.5 \mathrm{ka}$ ). The MIS3 transition started with a rapid warming $\left(+1.4^{\circ} \mathrm{C}\right.$ in $\left.0.6 \mathrm{ka}\right)$ and exhibited high variability (Fig. 3b). Late MIS2 presented a warming trend (Fig. 2b; Table 2), interrupted by cooling episodes at $17.5 \mathrm{ka}\left(-1.4^{\circ} \mathrm{C}\right)$ and at $11.8 \mathrm{ka}\left(-1.6^{\circ} \mathrm{C}\right)$ which could correspond to Heinrich event $1(\mathrm{H} 1)$ and the YD, respectively, as described at higher latitudes (Fig. 3b).

The above-mentioned criteria were useful for comparison of the sub-millennial-scale events identified in the Guiana Basin (Fig. 3c) with tropical cave records (Cheng et al., 2013, Mosblech et al., 2012) in which sub-millennial-scale events were also identified (Fig. 3e, f). The SSTs in Guiana Basin and the cave records had a similar pattern. Some D-O (Dansgaard-Oeschger) stadials were recorded as one struc- 
ture event but the number of events was sufficient to compare to the Greenland profiles.

\section{Discussion}

\subsection{Rapid tropical-pole connections during warm, stable periods}

During the last two interglacials (MIS1 and MIS5e) and warm long interstadials (MIS5d-a) both Greenland and Guiana experienced parallel cooling trends (Fig. 2a-b). Conversely, SSTs around MIS5b (82.7 ka) presented inverse long-term trends between Greenland and Guiana: polar latitudes showed a warming trend, while the tropical site experienced a cooling transition. The fact that the SSTs in MIS5e $\left(28.9^{\circ} \mathrm{C}\right)$ were higher than in the MIS1 $\left(28.3^{\circ} \mathrm{C}\right)$ further confirms previous observations which suggest a precessional modulation despite the differences between both interglacials (e.g. Martrat et al., 2014; Figs. 3b, 4b). Specifically, prolonged interglacial warmth in the North Atlantic after insolation minima ( $116.3 \mathrm{ka}$; Table 2$)$ has been attributed to a strengthening of the thermohaline circulation (McManus et al., 2002). Prominent drops in SST around MIS5d and MIS5b, features characteristic in the North Atlantic, occurred after precessional maxima (insolation minima; Fig. 4c). MIS5b comprises one of the most extreme events recorded in southern European pollen sequences (Tzedakis et al., 2003) that is in line with the maximum extension of the Barents-Kara and Scandinavian ice sheets (Svendsen et al., 2004). This increase blocked the drainage of north-east European rivers owing to the existence of large proglacial lakes (Krinner et al., 2004). During these cold events (MIS5c,d and $\mathrm{D}-\mathrm{O}$ stadials) ice sheet discharge increased, strengthening NE trade winds and reducing northward Guiana current heat transport (Chiang and Bitz, 2005, Maslin, 1998). In these stronger NE wind conditions, ITCZ shifted southward and NEC moved to the south, cooling the Caribbean region (Schmidt et al., 2004) and the Guiana Basin.

The warm MIS5a and MIS5c periods in Greenland and the two interglacials involved an ice sheet reduction and a lower SST gradient along the Atlantic, reducing NE trade winds' strength. These warmer SSTs favoured the northward shift of the ITCZ driven by SE trade winds which increased heat transport northward to the Caribbean Sea and North Atlantic higher latitudes. This active heat transport along the Atlantic Ocean can be observed in Fig. 2c where the AMOC is active and Guiana Basin SSTs warm as Greenland temperatures.

Opposite trends occurred in Guiana and Greenland during MIS3 and early MIS2 (Table 2). From MIS4 to MIS2, the DO-type oscillations constituted the background pattern of the observed climate variability (Figs. 3a, 4a). The SST changes observed in MD03-2616 were strongly modulated by precession (Figs. 3c, 4c). The overall SST profile showed a maximum fall of $-2.2{ }^{\circ} \mathrm{C}$ (see Fig. S3) which was much less than that observed in the North Atlantic, e.g. $-10^{\circ} \mathrm{C}$ in the Iberian

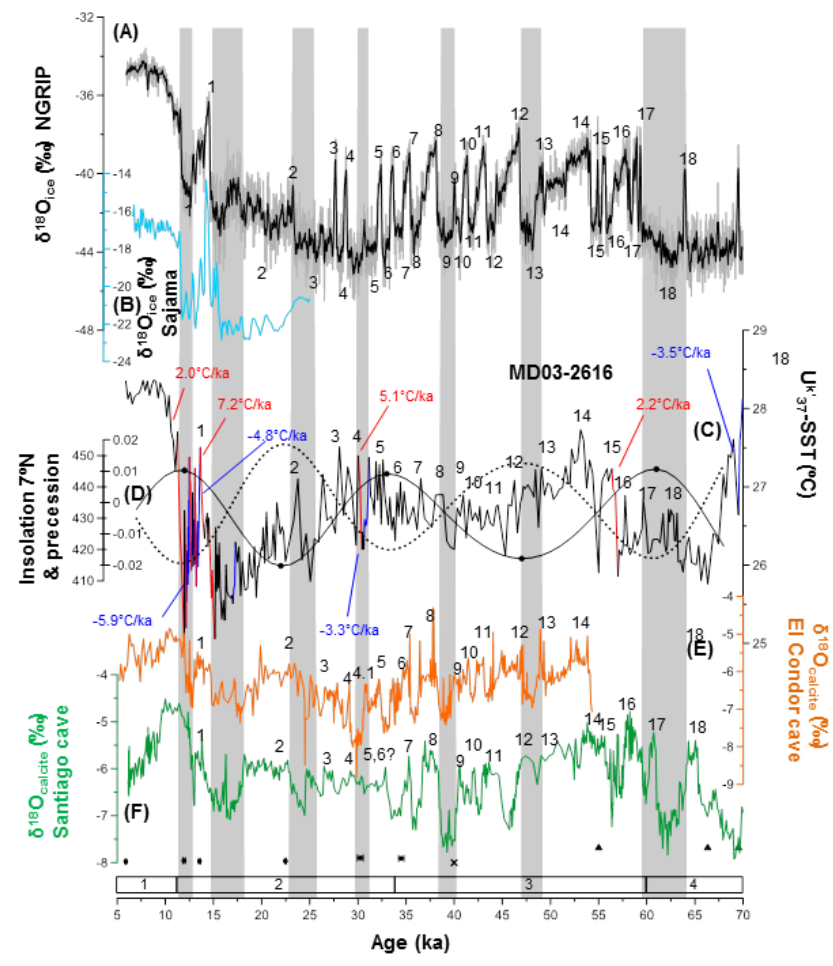

Figure 3. Abrupt changes over MIS4, MIS3 and MIS2. (a) $\delta^{18} \mathrm{O}_{\text {ice }}$ (\%o) measured in NGRIP (NGRIP, 2004; Wolff et al., 2010), (b) Sajama ice core (Thompson et al., 1998). (c) MD03-2616 $\mathrm{U}_{37}^{k^{\prime}}$-SST (this study). (d) Precession (dashed line) and daily insolation (solid line) at $7^{\circ} \mathrm{N}$ during the summer solstice (Berger, 1978). (e) $\delta^{18} \mathrm{O}_{\text {Caclcite }} \mathrm{El}$ Condor Cave (Cheng et al., 2013) (f) $\delta^{18} \mathrm{O}_{\text {Caclcite }}$ Santiago Cave (Mosblech et al., 2012). The abrupt changes identified in the MD03-2616 SST record are operationally defined as a transition faster than $2{ }^{\circ} \mathrm{C} \mathrm{ka}^{-1}$ and with absolute intensity equal to or higher than $0.5^{\circ} \mathrm{C}$ (Table 3 ). The blue and red lines represent abrupt cooling and warming SST changes, respectively.

Margin (Bard et al., 2000; Martrat et al., 2007) or $-6^{\circ} \mathrm{C}$ in the Alboran Sea (Martrat et al., 2004; Cacho et al., 1999). The lower SST amplitudes in the MD03-2616 site were consistent with the narrow SST range found in tropical regions.

During the latest stages of the last deglaciation, the MD032616 SSTs were a reminder of oscillations observed in Greenland (North Greenland Ice Core Project members, 2004), with structures similar to the B-A and the stadial associated with HE1, respectively (Fig. 3a and c). Once again, these SST changes were of lower intensity in the Guiana core than in higher latitudes of the Atlantic Ocean and the Iberian Margin (Martrat et al., 2007) but similar to those observed in the Senegal Basin (Niedermeyer et al., 2009) which was consistent with the common subdued SST variability in tropical regions. The parallel changes between Guiana and Greenland during the last deglaciation suggest that the advection of warm tropical waters into the North Atlantic amplified the thermohaline circulation and contributed to high-latitude warming (Knorr and Lohmann, 2003; Schmidt et al., 2004). 
Table 2. Trends between precession maxima and minima and vice-versa (insolation minima and maxima and vice-versa) from the marine isotope stage - MIS5e to MIS2 in Greenland (NGRIP; North Greenland Ice Core Project members, 2004), Guiana Basin (MD03-2616; this study), Cariaco Basin (ODP 1002C; Peterson et al., 2000) and off north-eastern Brazil (GeoB-3910; Jaeschke et al., 2007). N refers to the number of samples used to calculate the trends.

\begin{tabular}{|c|c|c|c|c|c|c|c|c|c|}
\hline \multirow[t]{2}{*}{ MIS } & \multirow[t]{2}{*}{ Age (ka BP) } & \multicolumn{2}{|c|}{ NGRIP } & \multicolumn{2}{|c|}{ MD03-2616 } & \multicolumn{2}{|c|}{ ODP 1002} & \multicolumn{2}{|c|}{ GeoB-3910 } \\
\hline & & $\% \circ \mathrm{ka}^{-1}$ & $\mathrm{~N}$ & ${ }^{\circ} \mathrm{C} \mathrm{ka}^{-1}$ & $\mathrm{~N}$ & $\% \mathrm{ka}^{-1}$ & $\mathrm{~N}$ & ${ }^{\circ} \mathrm{C} \mathrm{ka}^{-1}$ & $\mathrm{~N}$ \\
\hline \multirow[t]{2}{*}{2} & from 22.5 to 11.5 & 0.32 & 551 & 0.02 & 104 & 0.19 & 309 & 0.15 & 54 \\
\hline & from 33.6 to 22.5 & 0.01 & 556 & -0.04 & 41 & -0.09 & 248 & -0.06 & 43 \\
\hline \multirow[t]{2}{*}{3} & from 46.8 to 33.6 & -0.13 & 661 & 0.01 & 40 & 0.07 & 355 & 0.03 & 72 \\
\hline & from 60.1 to 46.8 & -0.04 & 666 & 0.05 & 62 & 0.43 & 300 & 0.02 & 47 \\
\hline 4 & from 71.6 to 60.1 & -0.16 & 576 & -0.16 & 63 & -0.26 & 192 & & \\
\hline $5 a$ & from 82.7 to 71.6 & -0.38 & 556 & -0.07 & 38 & -0.14 & 117 & & \\
\hline $5 b$ & from 94.2 to 82.7 & 0.08 & 576 & -0.04 & 50 & & & & \\
\hline $5 c$ & from 105.4 to 94.2 & -0.11 & 561 & -0.01 & 81 & & & & \\
\hline $5 d$ & from 116.3 to 105.5 & -0.08 & 541 & -0.03 & 45 & & & & \\
\hline $5 e$ & from 127.3 to 116.3 & -1.27 & 300 & -0.05 & 21 & & & & \\
\hline
\end{tabular}

Links between the Guiana SST record and those from the Agulhas area are expected, given that the former is located in the area of influence of the NBC originating from the SEC, providing salty warm waters to the western tropical Atlantic north of the equator (Fig. 1; Stramma and Schott, 1999). The SEC is ultimately fed by leakage from the Agulhas current (Peterson and Stramma, 1991; Bard and Rickaby, 2009; Caley et al., 2014). Intensification in the delivery of salt into the Atlantic may contribute to the strengthening of the AMOC flow. Hydrographical changes in equatorial currents have previously been put forward as a possible influence on the development and intensity of interglacial SSTs (Ganachaud and Wunsch, 2000; Trenberth and Caron, 2001). However, SST reconstructions influenced by the Agulhas current (Martinez-Mendez et al., 2010; Marino et al., 2013; Dyez et al., 2014; Bard and Rickaby, 2009) differ from the MD03-2616 SST record.

Conversely, the coupling between SST change in the MD03-2616 site, the Greenland temperatures, and the SST of northern Atlantic latitudes (Martrat et al., 2007) in the interglacials is consistent with the model describing an AMOC dependence on global mean air temperature anomalies and North Atlantic SSTs (Ritz et al., 2013). Analogous SST evolution between tropical areas and Greenland suggests that ocean processes in Guiana (stronger GC fed by SEC) were directly related to the AMOC strength during the last two interglacials (MIS5e and MIS1) and warm long interstadials (MIS5d-a). This parallel behaviour is in line with the amplification of thermohaline circulation resulting from the movement of warm tropical waters into the North Atlantic, as observed in cores from the Caribbean Sea $\left(12^{\circ} \mathrm{N}, 78^{\circ} \mathrm{W}\right.$; Schmidt et al., 2004). The coupling of the west tropical Atlantic waters with these processes was probably necessary for the supply of salty waters to the Caribbean Sea prior to concentration and advection towards the North Atlantic. The

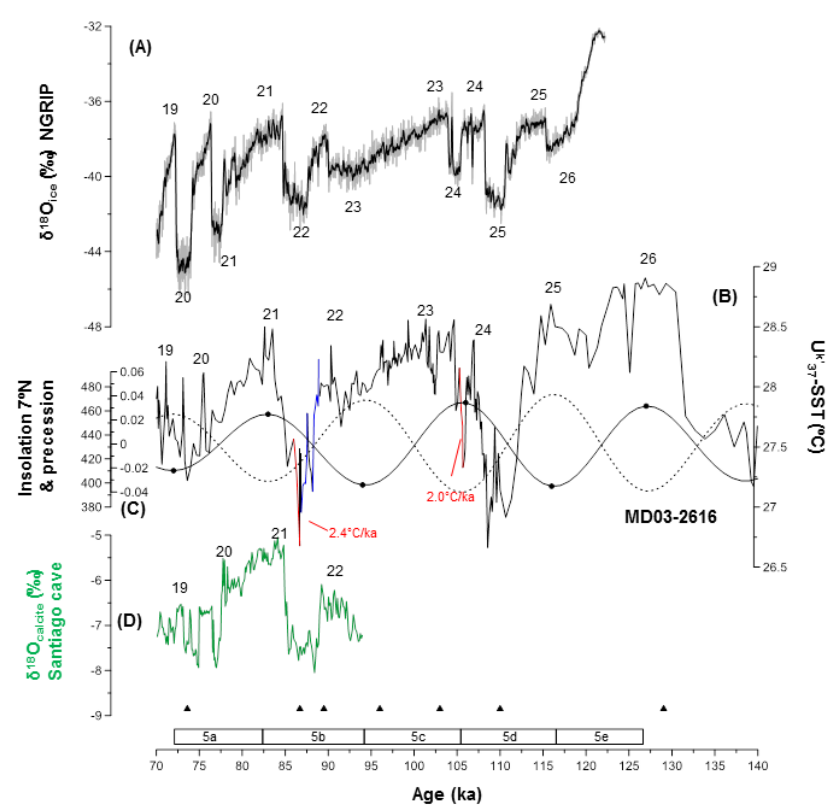

Figure 4. Abrupt changes over MIS5e-a. (a) $\delta^{18} \mathrm{O}_{\text {ice }}(\% \circ)$ measured in NGRIP (NGRIP, 2004; Wolff et al., 2010). (b) MD03-2616 $\mathrm{U}_{37}^{k^{\prime}}$-SST (this study). (c) Precession (dashed line) and daily insolation (solid line) at $7^{\circ} \mathrm{N}$ during the summer solstice (Berger, 1978). (d) $\delta^{18} \mathrm{O}_{\text {Caclcite }}$ Santiago Cave (Mosblech et al., 2012). The blue and red lines represent abrupt cooling and warming SST changes, respectively (higher than $0.5^{\circ} \mathrm{C}$ and $2{ }^{\circ} \mathrm{C} \mathrm{ka}^{-1}$ ). According to the Levitus database, the oxygen minimum zone in this area is located between 200 and $600 \mathrm{~m}$ (Levitus, 1982).

coupling is observed irrespective of the larger sediment yield from the Amazon River to the MD03-2616 site during interglacials. Possible local effects caused by Amazon discharges in this area did not significantly disturb the MD03-2616 SST 
record, which preserves a conspicuous parallelism between tropical climate changes and Greenland variability.

\subsection{Tropical abrupt SST changes during transitional intervals}

Abrupt changes occurred in the North Atlantic throughout MIS3 (Martrat et al., 2014), as in the Guiana Basin but at lower intensity $\left(1-1.5^{\circ} \mathrm{C}\right)$. Guiana SSTs show warming/cooling events that are a reminder of D-O oscillations and HEs in Greenland. HE1, 2, 3, and 4 constitute one of the main features of this pattern but it also has a tropical structure, consistent with the tropical South America cave records (Fig. 3e, f). Most abrupt changes (as defined in Sect. 4.3) occur during the termination (Fig. 3c; Table 3). This pattern is somewhat consistent with the events described above. MD03-2616 exhibits abrupt oscillations around the $\mathrm{B}-\mathrm{A}$. This feature has also been observed in the Sajama $\delta^{18} \mathrm{O}_{\text {ice }}$ continental ice record (Bolivia; Thompson et al., 1998), which reinforces the evidence of links between the climate changes in the North Atlantic and in central and south America during the end of the last deglaciation (Fig. 3a-b).

A strong SST variability in the YD has been identified in the high temporal resolution of MD03-2616. Bearing in mind that the YD most likely resulted from the massive discharge of cold freshwater into the North Atlantic, causing a decrease in the AMOC (Broecker and Hemming, 2001; Teller et al., 2002), it is feasible that such large freshwater inputs could modify oceanic circulation in the tropical Atlantic. The influence of these northern waters may have had an effect on latitudinal displacements of the ITCZ which may have also resulted in SST variations in Guiana. The onset of this cold period was very abrupt at the Guiana site, with SST decreases of ca. $-6^{\circ} \mathrm{C} \mathrm{ka}^{-1}$ and changes over $2{ }^{\circ} \mathrm{C}$.

During the glacial periods, the SST record of MD03-2616 shows significant variability, with oscillations of $0.5-1.2^{\circ} \mathrm{C}$. This represents about $30 \%$ of the maximum SST change during the glacial to interglacial transition $\left(3.8^{\circ} \mathrm{C}\right)$. This relative change is lower than that observed in more northern sites of the North Atlantic, such as the Blake Outer Ridge $(50 \%$ in ODP-1060; López-Martinez et al., 2006), the Iberian Margin (46\% in MD01-2044; Martrat et al., 2007) or the Alboran Sea (40\% in ODP-977; Martrat et al., 2004 or $46 \%$ in MD95-2043; Cacho et al., 1999). The sub-millennial variability of MD03-2616 during MIS3 is therefore lower than in the cores retrieved further north in the North Atlantic. Changes at high latitudes are stronger than in the tropics due to sea-ice-albedo feedbacks (Menviel et al., 2014).

\subsection{Glacial see-saw between the tropics and Greenland}

Previously published data sets are available to assess the significance of trends and events observed in Greenland (Fig. 5a) and in Guiana during the glacial. Long term trends in ODP $1002 \mathrm{C}$ reference core from the Cariaco Basin (ca.

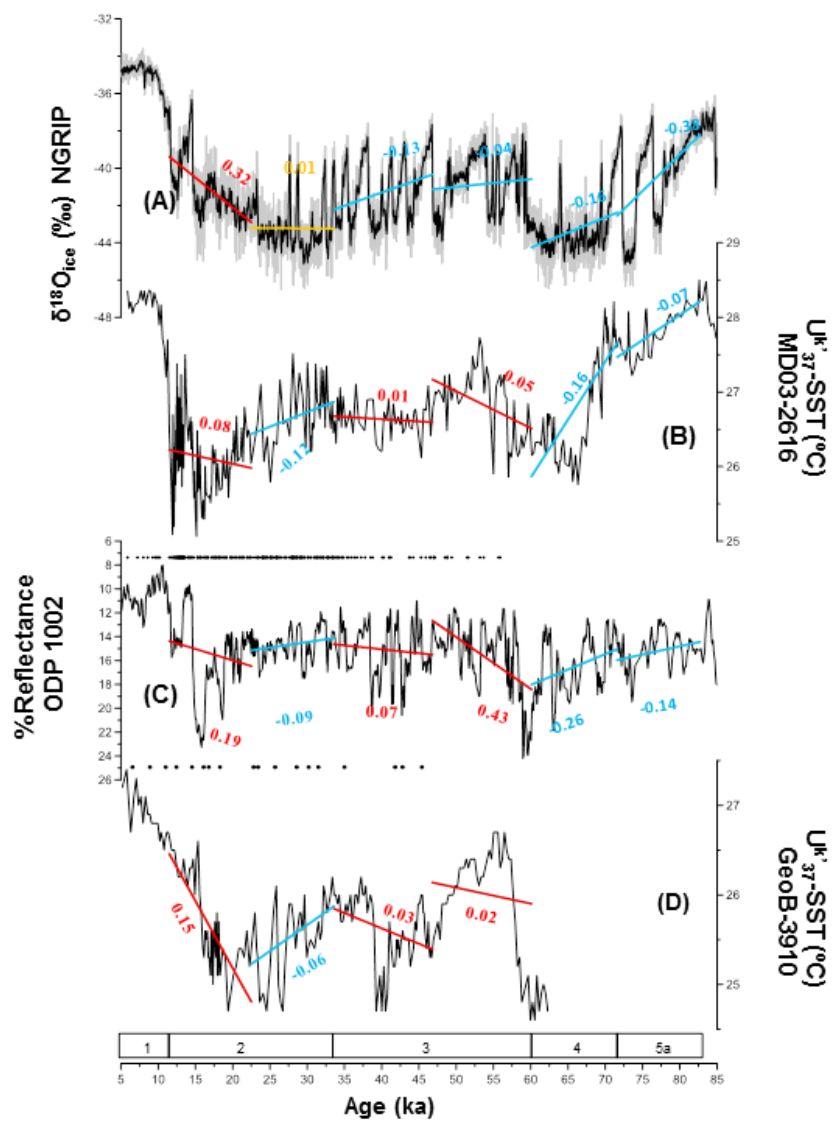

Figure 5. Glacial see-saw between Greenland and Guiana (a) $\delta^{18} \mathrm{O}_{\text {ice }}$ measured in NGRIP (NGRIP, 2004; Wolff et al., 2010) (b) MD03-2616 $\mathrm{U}_{37}^{k^{\prime}}$-SST (this study). (c) \% reflectance in ODP 1002, Cariaco (Peterson et al., 2000). (d) GeoB-3910 U $\mathrm{U}_{37}^{\prime}-\mathrm{SST}$, north-eastern Brazil (Jaeschke et al., 2007). The trends between precession maxima and minima and vice-versa are shown. The numbers close to the trends refer to the values in Table 2. Radiocarbon dates are drawn as dots on the top of the ODP 1002 and GeoB-3910 profiles.

72 radiocarbon dates; $10^{\circ} \mathrm{N}, 65^{\circ} \mathrm{W}$; Peterson et al., 2000) are in line with the trends observed in Guiana for the time span in which they overlap (Fig. 5b, c). In the nearby core MD03-2622 $\left(10^{\circ} \mathrm{N}, 65^{\circ} \mathrm{W}\right)$, the vegetation patterns are consistent with the rapid variability of Greenland (Gonzalez et al., 2008). Changes in Cariaco (reflectance and vegetation) are directly influenced by ITCZ shifts southward which are linked to the SST changes in Guiana. Comparison of these two proxies influenced by the same climate process provides information on the consistency of the overall interpretation of the results. Similarly, the extent to which the well-dated SST record in GeoB 3910-2 (Jaeschke et al., 2007) agrees with the long trends observed in Guiana supports that these tropical cores show analogous patterns to the Greenland rapid oscillations but also display a robust precessional forcing response (Fig. 5d). 
Table 3. List of the abrupt SST changes identified in the MD03-2616 core. They are defined as positive or negative increments represented by $\geq 3$ samples, occurring faster than the average SST warming during the last deglaciation, $+2^{\circ} \mathrm{C} \mathrm{ka}^{-1}\left(3.1^{\circ} \mathrm{C}\right.$ in 1550 years in this SST record), and higher than $\pm 0.5^{\circ} \mathrm{C}$.

\begin{tabular}{|c|c|c|c|c|c|c|c|c|c|c|c|}
\hline MIS & Events & $\begin{array}{r}\text { Onset } \\
\mathrm{cm}\end{array}$ & $\begin{array}{r}\text { End } \\
\mathrm{cm}\end{array}$ & $\begin{array}{r}\text { Onset } \\
\mathrm{Ka}\end{array}$ & $\begin{array}{r}\text { End } \\
\mathrm{Ka}\end{array}$ & $\begin{array}{r}\text { Onset } \\
{ }^{\circ} \mathrm{C}\end{array}$ & $\begin{array}{l}\text { End } \\
{ }^{\circ} \mathrm{C}\end{array}$ & $\begin{array}{l}\Delta \\
{ }^{\circ} \mathrm{C}\end{array}$ & $\begin{array}{r}\Delta \\
\text { age }\end{array}$ & ${ }^{\circ} \mathrm{C} \mathrm{ka}^{-1}$ & Equivalence \\
\hline \multirow[t]{6}{*}{2} & 1 & 28 & 25 & 11.94 & 11.27 & 25.09 & 27.70 & 2.6 & 0.7 & 3.9 & YD/Holocene \\
\hline & 2 & 34 & 30 & 12.14 & 12.01 & 25.20 & 26.69 & 1.5 & 0.1 & 11.2 & Intra YD \\
\hline & 3 & 51 & 45 & 12.71 & 12.51 & 25.94 & 27.38 & 1.4 & 0.2 & 7.2 & Intra $\mathrm{B}-\mathrm{A}$ \\
\hline & 4 & 66 & 62 & 13.21 & 13.07 & 25.73 & 27.24 & 1.5 & 0.1 & 11.3 & Intra $\mathrm{B}-\mathrm{A}$ \\
\hline & 5 & 82 & 77 & 14.08 & 13.63 & 26.34 & 27.50 & 1.2 & 0.4 & 2.6 & Intra $\mathrm{B}-\mathrm{A}$ \\
\hline & 6 & 94 & 87 & 15.15 & 14.52 & 25.06 & 26.60 & 1.5 & 0.6 & 2.5 & HE1/B-A \\
\hline \multirow[t]{2}{*}{3} & 7 & 214 & 211 & 30.42 & 30.02 & 26.20 & 27.39 & 1.2 & 0.4 & 3.0 & GS5/GI4 \\
\hline & 8 & 400 & 395 & 57.00 & 56.38 & 25.86 & 27.23 & 1.4 & 0.6 & 2.2 & GS16/GI15 \\
\hline \multirow[t]{2}{*}{5} & 9 & 701 & 693 & 87.56 & 87.19 & 26.68 & 27.57 & 0.9 & 0.4 & 2.4 & GS22/GI21 \\
\hline & 10 & 1129 & 1121 & 105.68 & 105.27 & 27.33 & 28.16 & 0.8 & 0.4 & 2.0 & $\mathrm{GS} 24 / \mathrm{G}+\mathrm{I} 23$ \\
\hline \multirow[t]{6}{*}{2} & 1 & 45 & 34 & 12.51 & 12.14 & 27.38 & 25.20 & -2.2 & 0.4 & -5.9 & $\mathrm{~B}-\mathrm{A} / \mathrm{YD}$ \\
\hline & 2 & 55 & 51 & 12.84 & 12.71 & 26.93 & 25.94 & -1.0 & 0.1 & -7.4 & $\mathrm{~B}-\mathrm{A} / \mathrm{YD}$ \\
\hline & 3 & 59 & 56 & 12.97 & 12.87 & 26.58 & 25.99 & -0.6 & 0.1 & -5.9 & $\mathrm{~B}-\mathrm{A} / \mathrm{YD}$ \\
\hline & 4 & 62 & 56 & 13.07 & 12.87 & 27.24 & 25.99 & -1.3 & 0.2 & -6.3 & $\mathrm{~B}-\mathrm{A} / \mathrm{YD}$ \\
\hline & 5 & 77 & 66 & 13.63 & 13.21 & 27.50 & 25.73 & -1.8 & 0.4 & -4.2 & Intra $\mathrm{B}-\mathrm{A}$ \\
\hline & 6 & 118 & 115 & 17.29 & 17.02 & 26.29 & 25.51 & -0.8 & 0.3 & -2.9 & HE1 \\
\hline 3 & 7 & 222 & 216 & 31.15 & 30.60 & 27.37 & 26.21 & -1.2 & 0.5 & -2.1 & HE3 \\
\hline 4 & 8 & 505 & 499 & 69.94 & 69.52 & 28.12 & 26.64 & -1.5 & 0.4 & -3.5 & GI19/GS19 \\
\hline \multirow[t]{2}{*}{5} & 9 & 722 & 705 & 87.56 & 86.86 & 27.78 & 26.95 & -0.8 & 0.2 & -5.0 & GI22/GS22 \\
\hline & 10 & 754 & 737 & 88.88 & 88.18 & 28.23 & 27.13 & -1.1 & 0.4 & -3.0 & GI22/GS22 \\
\hline
\end{tabular}

Lacustrine records of Central America from Lake Petén Itzá (Guatemala, $17^{\circ} \mathrm{N}, 89^{\circ} \mathrm{W}$; Hodell et al., 2008) also follow the MIS3 abrupt variability recorded in Greenland ice. This variability in Guatemala was due to ITCZ displacements. Model simulations of hydrological perturbations over the northern Atlantic, due to the growth of ice sheets or iceberg delivery, were shown to induce a southward shift of the ITCZ over the tropical Atlantic region (Chiang and Bitz, 2005, Kageyama et al., 2013, Menviel et al., 2014). This southward shift was recorded in reconstructions based on palynologic (Gonzalez et al., 2008) and lithogenic (Peterson et al., 2000, Wang et al., 2004) components (e.g. Ti / Ca or $\mathrm{Fe} / \mathrm{Ca}$ ratios, or continental organic matter inputs) in Brazilian cores, which follow sedimentation pulses paralleling those recorded during Heinrich events (Jennerjahn et al., 2004; Nace et al., 2014). Hence, the influence of abrupt climate variations in the North Atlantic and Greenland arrived at low latitudes, such as in the tropical regions. These results show that the marine and continental climate of northern South America was connected with polar variability during glacial periods which was overall dominated by precessional forcing.

GeoB3910-2 and MD03-2616 have the same long trend (SEC influence, Fig. S4c, d) but different patterns in the short trend due to the influence of NEC in the second (Fig. S4b, c). The MD03-2616 is located in the confluence of Northern (NEC) and Southern Hemisphere waters (NBC, SEC). Obviously, both types of currents could a priori influence SSTs. A comparison of the $\mathrm{U}_{37}^{k^{\prime}}-\mathrm{SST}$ records under the influence of these currents (Schneider et al., 1999, Simon et al., 2013, Dyez et al., 2014) and Guiana SSTs has been tentatively attempted despite the differences in time resolution (Fig. S4). The equatorial Atlantic SST record of GeoB1105 core is consistent with the Agulhas pattern (Schneider et al., 1996) and has a parallelism with the SST record of GeoB 3910 (Jaeschke et al., 2007, Weldeab et al., 2006) that is under the influence of SEC and NBC waters. SST dynamics of the Agulhas current has been attributed to poleward displacements of the subtropical front of the Southern Hemisphere which coincides with warm intervals south of Africa in the western Atlantic Ocean (De Dekker et al., 2012). MD03-2616 shows a different SST variability that is closest to the SST profiles of the cores under the influence of the NEC (Niedermeyer et al., 2009) than the Brazilian cores. This northern influence is also clear in the interglacial in which SST from MD032616 and MD01-2343 (Martrat et al., 2007) show significant parallelisms. The lack of consistent SST change in MD032616 and the cores from the Agulhas area or the northeastern tropical Atlantic during the last glacial period (Zarries et 
al., 2011) evidence the long-term decoupling trend between these geographic areas during low intensity of the AMOC.

\section{Conclusions}

The SSTs in the western tropical Atlantic (MD03-2616; Guiana Basin) over the past 140 ka ranged from 25.1 (MIS2) to $28.9^{\circ} \mathrm{C}$ (MIS5e), i.e. a glacial-interglacial amplitude of $3.8^{\circ} \mathrm{C}$, in the same range as observed in other tropical areas. The SSTs during the MIS1 $\left(28.3^{\circ} \mathrm{C}\right)$ were lower than in MIS5e, which is consistent with observations from previous studies at North Atlantic latitudes. MIS5b and MIS5d decreases were much smaller than those observed in the Atlantic Ocean at higher latitudes, though proportional to the subdued glacial-interglacial SST range of tropical regions.

The SSTs in Guiana show a remarkable parallelism with the temperature changes observed in Greenland from MIS5e to MIS5a, suggesting a close connection between tropical and Arctic-Atlantic latitudes in these periods. A possible mechanism to explain this connection is the transport of warm waters from the Caribbean Sea to North Atlantic latitudes when the whole AMOC was active and strong, thereby facilitating the thermohaline transmission role resulting from the transfer of tropical waters into the North Atlantic.

Abrupt transitions have been identified in core MD032616. Some of these changes are observed in MIS5d and MIS5b but are much more commonly found during transitional periods from MIS4 to MIS2. The influence of northern waters (NEC) during deglaciation periods may have had an effect on the latitudinal displacements of the ITCZ, which could also have increased SST variability in Guiana. The SSTs in MD03-2616 exhibit a strong abrupt warming and cooling changes coincident with the $\mathrm{B}-\mathrm{A}$. This variability has also been observed in the $\delta^{18} \mathrm{O}_{\text {ice }}$ record of Sajama, a Bolivian ice core. Both sites show a very abrupt end of the YD (rates of $4{ }^{\circ} \mathrm{C} \mathrm{ka}^{-1}$ and more than a $2.5^{\circ} \mathrm{C}$ change in MD032616).

The SSTs of MD03-2616 show significant variability in large sections of MIS3, comprising oscillations of $0.5-$ $1.2{ }^{\circ} \mathrm{C}$, which represent about $30 \%$ of the maximum glacialinterglacial SST change of $3.8^{\circ} \mathrm{C}$. This change is lower than that observed in the northern North Atlantic. During MIS3 and early MIS2, the SST record in Guiana appears to balance changes in the characteristic long-term trend observed at higher latitudes. When Greenland experienced a cooling trend Guiana showed a warming or, vice versa, Greenland remained stable when Guiana experienced a cooling trend. This lack of synchrony is consistent with SST records in northern and southern locations of the Atlantic Ocean (Cariaco and Brazil, respectively) and evidences the decoupling between these areas when the AMOC weakens.

\section{The Supplement related to this article is available online at doi:10.5194/cp-11-1297-2015-supplement.}

Acknowledgements. The work presented here has been co-funded by research projects CTM2014-59111-REDC and Past4Future (FP7-ENV-2009-1-243908). B. Martrat thanks CSICJAE-Doc and Ramon y Cajal post-doctoral contracts. The IMAGES Program and the scientific and technical cruise of the PICASSO expedition on board the R/V Marion Dufresne II are thanked for their efforts in the retrieval of core MD03-2616. We are also grateful to the Latin American Abrupt Climate Changes and Environmental Responses (LaACER) initiative.

Edited by: D. Urrego

\section{References}

Allen, J. R. M., Brandt, U., Brauer, A., Hubberten, H.-W., Huntley, B., Kellerk, J., Kramlk, M., Mackensen, A., Mingram, J., Negendank, J. F. W., Nowaczyk, N. R., Oberhansli, H. Watts, W. A., Wulf, S., and Zolitschka, B.: Rapid environmental changes in southern Europe during the last glacial period, Nature, 400, 740-743, 1999.

Arnault, S.: Tropical Atlantic geostrophic currents and ship drifts, J. Geophys. Res.-Oceans, 92, 5076-5088, 1987.

Bard, E. and Rickaby, E. M.: Migration of the subtropical front as a modulator of glacial climate, Nature, 460, 380-384, 2009.

Bard, E., Rostek, F., Turon, J.- L., and Gendreau, S.: Hydrological impact of Heinrich events in the subtropical northeast Atlantic, Science, 289, 1321-1324, 2000.

Barker, S., Knorr, G., Edwards, R. L., Parrenin, F., Putnam, A. E., Skinner, L. C., Wolff, E., and Ziegler, M.: 800000 years of abrupt climate variability, Science, 334, 347-351, 2011.

Barker, S., Chen, J., Gong, X., Jonkers, L., Knorr, G., and Thornalley, D.: Icebergs not the trigger for North Atlantic cold events, Nature, 520, 333-336, 2015.

Berger, A.: Long-Term Variations of Daily Insolation and Quaternary Climatic Changes, J. Atmos. Sci., 35, 2362-2367, 1978.

Bohm, E., Lippold, J., Gutjahr, M., Frank, M., Blaser, P., Antz, B., Fohlmeister, J., Frank, N., Andersen, M. B., and Deininger, M.: Strong and deep Atlantic meridional overturning circulation during the last glacial cycle, Nature, 517, 73-76, 2015.

Bond, G., Broecker, W., Johnsen, S., McManus, J., Labeyrie, L., Jouzel, J., and Bonani, G.: Correlations between climate records from North Atlantic sediments and Greenland ice, Nature 365, 143-147, 1993.

Bourlès, B., Gouriou, Y., and Chuchla, R.: On the circulation in the upper layer of the western equatorial Atlantic, J. Geophys. Res. Oceans, 104, 21151-21170, 1999.

Brassell, S. C., Eglinton, G., Marlowe, I. T., Pflaumann, U., and Sarnthein, M.: Molecular stratigraphy: A new tool for climatic assessment, Nature, 320, 129-133, 1986.

Broecker, W. S. and Hemming, S.: Climate swings come into focus, Science, 294, 2308-2309, 2001.

Cacho, I., Grimalt, J. O., Pelejero, C., Canals, M., Sierro, F. J., Flores J. A., and Shackleton, N.: Dansgaard-Oeschger and Heinrich event imprints in Alboran Sea paleotemperatures, Paleoceanography, 14, 698-705, 1999.

Cacho, I., Shackleton, N., Elderfield, H., Sierro, F. J., and Grimalt, J. O.: Glacial rapid variability in deep water temperature and $\delta^{18} \mathrm{O}$ from the Western Mediterranean Sea, Quat. Sci. Rev., 25, 3294 3311, 2006. 
Caley, T., Roche, D. M., Waelbroeck, C., and Michel, E.: Oxygen stable isotopes during the Last Glacial Maximum climate: perspectives from data-model (iLOVECLIM) comparison, Clim. Past, 10, 1939-1955, 2014, http://www.clim-past.net/10/1939/2014/.

Cheng, H., Edwards, R. L., Broecker, W. S., Denton, G. H., Kong, X., Wang, Y., Zhang, R., and Wang, X.: Ice Age Terminations, Science, 326, 248-252, 2009.

Cheng, H., Sinha, A., Cruz, F. W., Wang, X., Edwards, R. L., d'Horta, F. M., Ribas, C. C., Vuille, M., Stott, L. D., and Auler, A. S.: Climate change patterns in Amazonia and biodiversity, Nat. Commun., 4, 1-6, 2013.

Chiang, J. H. and Bitz, C.: Influence of high latitude ice cover on the marine Intertropical Convergence Zone, Clim. Dynam. 25, 477-496, 2005.

De Dekker, P., Moros, M., Perner, K., and Jansen, E.: Influence of the tropics and southern westerlies on glacial interhemispheric asymmetry, Nat. Geosci., 5, 266-269, 2012.

Dubois, N., Kienast, M., Kienast, S. S., and Timmermann, A.: Millennial-scale Atlantic/East Pacific sea surface temperature linkages during the last 100000 years, Earth Planet Sci., 396, 134-142, 2014.

Dyez, K. A., Zahn, R., and Hall, I. R.: Multicentennial Agulhas leakage variability and linls to north Atlantic climate during the past 800000 years, Paleoceanography, 29, 1238-1248, 2014.

EPICA community members: Eight glacial cycles from an Antarctic ice core, Nature, 429, 623-628, 2004.

Ericson, D. B. and Wollin, G.: Correlation of six cores from the equatorial Atlantic and the Caribbean, Deep Sea Res., 3, 104$125,1956$.

Ganachaud, A. and Wunsch, C.: Improved estimates of global ocean circulation, heat transport and mixing from hydrographic data, Nature, 408, 453-456, 2000.

Ganopolski, A. and Rahmstorf, S.: Rapid changes of glacial climate simulated in a coupled climate model, Nature, 409, 153158, 2001.

Gherardi, J. M., Labeyrie, L., Nave, S., Francois, R., McManus, J. F., and Cortijo, E.: Glacial-interglacial circulation changes inferred from ${ }^{231} \mathrm{~Pa} /{ }^{230} \mathrm{Th}$ sedimentary record in the North Atlantic region, Paleoceanography, 24, PA2204, doi:10.1029/2008PA001696, 2009.

González, C., Dupont, L. M., Behling, H., and Wefer, G.: Neotropical vegetation response to rapid climate changes during the last glacial period: Palynological evidence from the Cariaco Basin, Quat. Res., 69, 217-230, 2008.

Govin, A., Chiessi, C. M., Zabel, M., Sawakuchi, A. O., Heslop, D., Hörner, T., Zhang, Y., and Mulitza, S.: Terrigenous input off northern South America driven by changes in Amazonian climate and the North Brazil Current retroflection during the last $250 \mathrm{ka}$, Clim. Past, 10, 843-862, doi:10.5194/cp-10-843-2014, 2014.

Grimalt, J. O. and Lopez, J. F.: Alkenone paleothermometry from coccoliths, in: Encyclopedia of Quaternary Science, edited by: Scott, Elsevier, Amsterdam, 1610-1617, 2007.

Grimalt, J. O., Calvo, E., and Pelejero, C.: Sea surface paleotemperature errors in $\mathrm{U}_{37}^{k^{\prime}}$ estimation due to alkenone measurements near the limit of detection, Paleoceanography, 16, 226232, 2001.

Hendy, I. L., Kennett, J. P., Roark, E. B., and Ingram, B. L.: Apparent synchroneity of submillennial scale climate events between
Greenland and Santa Barbara Basin, California from 30-10 ka, Quat. Sci. Rev., 21, 1167-1184, 2002.

Herbert, T. D. and Schuffert, J. D.: Alkenone unsaturation estimates of sea-surface temperatures at site 1002 over a full glacial cycle, in: Proceedings of the Ocean Drilling Program, edited by: Leckie, R. M., Sigurdsson, H., Acton, G. D., and Draper, G., Scientific Results, 165, 239-247, 2000.

Hodell, D. A., Anselmetti, F. S., Ariztegui, D., Brenner, M., Curtis, J. H., Gilli, A., Grzesik, D. A., Guilderson, T. J., Müller, A. D., Bush, M. B., Correa-Metrio, A., Escobar, J., and Kutterolf, S.: An 85-ka record of climate change in lowland Central America, Quat. Sci. Rev., 27, 1152-1165, 2008.

Jaeschke, A., Rühlemann, C., Arz, H., Heil, G., and Lohmann, G.: Coupling of millennial-scale changes in sea surface temperature and precipitation off northeastern Brazil with high-latitude climate shifts during the last glacial period, Paleoceanography, 22, PA4206, doi:10.1029/2006PA001391, 2007.

Jennerjahn, T. C., Ittekkot, V., Arz, H. W., Behling, H., Patzold, J., and Wefer, G.: Asynchronous Terrestrial and Marine Signals of Climate Change During Heinrich Events, Science, 306, 22362239, 2004.

Jouzel, J., Masson-Delmotte, V., Cattani, O., Dreyfus, G., Falourd, S., Hoffmann, G., Minster, B., Nouet, J., Barnola, J. M., Chappellaz, J., Fischer, H., Gallet, J. C., Johnsen, S., Leuenberger, M., Loulergue, L., Luethi, D., Oerter, H., Parrenin, F., Raisbeck, G., Raynaud, D., Schilt, A., Schwander, J., Selmo, E., Souchez, R., Spahni, R., Stauffer, B., Steffensen, J. P., Stehni, B., Stocker, T. F., Tison, J. L., Werner, M., and Wolff, E. W.: Orbital and millennial antarctic climate variability over the past 800000 years, Science, 317, 793-796, 2007.

Kageyama, M., Merkel, U., Otto-Bliesner, B., Prange, M., AbeOuchi, A., Lohmann, G., Ohgaito, R., Roche, D. M., Singarayer, J., Swingedouw, D., and X Zhang: Climatic impacts of fresh water hosing under Last Glacial Maximum conditions: a multimodel study, Clim. Past, 9, 935-953, doi:10.5194/cp-9-9352013, 2013.

Keigwin, L. D. and Boyle, E. A.: Surface and deep ocean variability in the northern Sargasso Sea during marine isotope stage 3, Paleoceanography, 14, 164-170, 1999.

Kennett, J. P. and Huddlestun, P.: Late Pleistocene paleoclimatology, foraminiferal biostratigraphy and tephrochronology, western Gulf of Mexico, Quat. Res., 2, 38-69, 1972.

Knorr, G. and Lohmann, G.: Southern Ocean origin for the resumption of Atlantic thermohaline circulation during deglaciation, Nature, 424, 532-536, 2003.

Knutti, R., Fluckiger, J., Stocker, T. F., and Timmermann, A.: Strong hemispheric coupling of glacial climate through freshwater discharge and ocean circulation, Nature, 430, 851-856, 2004.

Krinner, G., Mangerud, J., Jakobsson, M., Crucifix, M., Ritz, C., and Svendsen, J. I.: Enhanced ice sheet growth in Eurasia owing to adjacent ice-dammed lakes, Nature, 427, 429-432, 2004.

Lankhorst, M., Fratantoni, D., Ollitrault, M., Richardson, P., Send, U., and Zenk, W.: The mid-depth circulation of the northwestern tropical Atlantic observed by floats, Deep-Sea Res. Pt. I, 56, 1615-1632, 2009.

Levitus, S. E.: Climatological atlas of the world ocean, NOAA Professional Paper 13, US Government Printing Office, Washington DC, 1-173, 1982. 
Lippold, J., Luo, Y., François, R., Allen, S. E., Gherardi, J., Pichat, S., Hickey, B., and Schulz, H.: Strength and geometry of the glacial Atlantic Meridional Overturning Circulation, Nat. Geosci., 5, 813-816, 2012.

Lisiecki, L. E. and Raymo, M. E.: A Pliocene-Pleistocene stack of 57 globally distributed benthic $\delta^{18} \mathrm{O}$ records, Paleoceanography, 20, PA1003, doi:10.1029/2004pa001071, 2005.

Lopez, J. F. and Grimalt, J. O.: Reassessment of the structural composition of the alkenone distributions in natural environments using an improved method for double bond location based on GCMS analysis of cyclopropylimines, J. Am. Soc. Mass Spectrom., 17, 710-720, 2006.

López-Martínez, C., Grimalt, J. O., Hoogakker, B., Gruetzner, J., Vautravers, M. J., and McCave, I. N.: Abrupt wind regime changes in the North Atlantic Ocean during the past 30000-60000 years, Paleoceanography, 21, PA4215, doi:10.1029/2006PA001275, 2006.

López-Otálvaro, G. E., Flores, J. A., Sierro, F. J., Cacho, I., Grimalt, J. O., Michel, E., Cortijo, E., and Labeyrie, L.: Late pleistocene palaeoproductivity patterns during the last climatic cycle in the Guyana Basin as revealed by calcareous nannoplankton, eEarth, 4, 1-13, 2009.

Loulergue, L., Schilt, A., Spahni, R., Masson-Delmotte, V., Blunier, T., Lemieux, B., Barnola, J.-M., Raynaud, D., Stocker, T. F., and Chappellaz, J.: Orbital and millennial-scale features of atmospheric $\mathrm{CH}_{4}$ over the past 800000 years, Nature, 453, 383386,2008

MARGO project Members: Constraints on the magnitude and patterns of ocean cooling at the Last Glacial Maximum, Nat. Geosci., 2, 127-132, 2009.

Marino, G., Zahn, R., Ziegler, M., Purcell, C., Knorr, G., Hall, I. R., Ziveri, P., and Elderfield, H.: Agulhas salt-leakage oscillations during abrupt climate changes of the late Pleistocene, Paleoceanography, 28, 599-606, 2013.

Martinez-Mendez, G., Zahn, R., Hall, I. R., Peeters, F. J. C., Pena, L. D., Cacho, I., and Negre, C.: Contrasting multiproxy reconstructions of surface ocean hydrography in the Agulhas Corridor and implications for the Agulhas leakage during the last 345000 years, Paleoceanography, 25, PA4227, doi:10.1029/2009PA001879, 2010.

Martrat, B., Grimalt, J. O., Lopez-Martinez, C., Cacho, I., Sierro, F. J., Flores, J. A., Zahn, R., Canals, M., Curtis, J. H., and Hodell, D. A.: Abrupt temperature changes in the Western Mediterranean over the past 250000 years, Science, 306, 1762-1765, 2004.

Martrat, B., Grimalt, J. O., Shackleton, N. J., De Abreu, L., Hutterli, M. A., and Stocker, T. F.: Four climate cycles of recurring deep and surface water destabilizations on the Iberian margin, Science, 317, 502-507, 2007.

Martrat, B., Jimenez-Amat, P., Zahn, R., and Grimalt, J. O.: Similarities and dissimilarities between the last two deglaciations and interglaciations in the North Atlantic region, Quat. Sci. Rev., 99, 122-134, 2014.

Maslin, M.: Equatorial western Atlantic Ocean circulation changes linked to the Heinrich events: deep-sea sediment evidence from the Amazon Fan, Geological Society, London, Special Publications, 131, 111-127, 1998.

Maslin, M. A., Durham, E., Burns, S. J., Platzman, E., Grootes, P., Greig, S. E. J., Nadeau, M. J., Schleicher, M., Pflaumann, U., Lomax, B., and Rimington, N.: Palaeoreconstruction of the Amazon
River freshwater and sediment discharge using sediments recovered at site 942 on the Amazon Fan, J. Quaternary Sci., 15, 419434, 2000.

Maslin, M. A., Ettwein, V. J., Boot, C. S., Bendle, J., and Pancost, R. D.: Amazon Fan biomarker evidence against the Pleistocene rainforest refuge hypothesis?, J. Quaternary Sci., 27, 451-460, 2012.

Masson, S. and Delecluse, P.: Influence of the Amazon river runoff on the tropical atlantic, Phys. Chem. Earth Pt. B, 26, 137-142, 2001.

McManus, J. F., Bond, G. C., Broecker, W. S., Johnsen, S., Labeyrie, L., and Higgins, S.: High-resolution climate records from the North Atlantic during the last interglacial, Nature, 371, 326-329, 1994.

McManus, J. F., Oppo, D. W., Keigwin, L. D., Cullen, J. L., and Bond, G. C.: Thermohaline circulation and prolonged interglacial warmth in the North Atlantic, Quarter. Res, 58, 17-21, 2002.

McManus, J. F., Francois, R., Gherardi, J-M., and Keigwin, L. D.: Collapse and rapid resumption of Atlantic meridional circulation linked to deglacial climate changes, Nature, 428, 834-837, 2004.

Menviel, L., Timmermann, A., Friedrich, T., and England, M. H.: Hindcasting the continuum of Dansgaard-Oeschger variability: mechanisms, patterns and timing, Clim. Past, 10, 63-77, doi:10.5194/cp-10-63-2014, 2014.

Mosblech, N. A. S., Bush, M. B., Gosling, W. D., Hodell, D., Thomas, L., van Calsteren, P., Correa-Metrio, A., Valencia, B. G., Curtis, J., and van Woesik, R.: North Atlantic forcing of Amazonian precipitation during the last ice age, Nat. Geosci., 5, 817820, 2012.

Muller-Karger, F. E., McClain, C. R., and Richardson, P. L.: The dispersal of the Amazon's water, Nature, 333, 56-59, 1988.

Muller-Karger, F. E., McClain, C. R., Fisher, T. R., Esaias, W. E., and Varela, R.: Pigment distribution in the Caribbean sea: Observations from space, Prog. Oceanogr., 23, 23-64, 1989.

Muller-Karger, F. E., Richardson, P. L., and McGillicuddy, D.: On the offshore dispersal of the Amazon's Plume in the North Atlantic: Comments on the paper by A. Longhurst, "Seasonal cooling and blooming in tropical oceans", Deep-Sea Res. Pt. I, 42, 2127-2131, 1995.

Müller, P. J., Kirst, G., Ruhland, G., Von Storch, I., and RosellMele, A.: Calibration of the alkenone paleotemperature index U37 K based on core-tops from the eastern South Atlantic and the global ocean $\left(60^{\circ} \mathrm{N}-60^{\circ} \mathrm{S}\right)$, Geochim. Cosmochim. Ac., 62, 1757-1772, 1998.

Nace, T. E., Baker, P. A., Dwyer, G. S., Silva, C. G., Rigsby, C. A., Burns, S. J., Giosan, L., Otto-Bliesner, B., Liu, Z., and Zhu, J.: The role of North Brazil current transport in the paleoclimate of the Brazilian Nordeste margin and paleoceanography of the western tropical Atlantic during the late Quaternary, Palaeogeogr. Palaeoecol., 415, 3-13, 2014.

NEEM community members.: Eemian interglacial reconstructed from a Greenland folded ice core, Nature, 493, 489-494, 2013.

Niedermeyer, E. M., Prange, M., Mulitza, S., Mollenhauer, G., Schefuss, E., and Schulz, M.: Extratropical forcing of Sahel aridity during Heinrich stadials, Geophys. Res. Lett., 36, L20707, doi:10.1029/2009g1039687, 2009. 
North Greenland Ice Core Project members.: High-resolution record of Northern Hemisphere climate extending into the last interglacial period, Nature, 431, 147-151, 2004.

Oppo, D. W., Keigwin, L. D., McManus, J. F., and Cullen, J. L.: Persistent suborbital climate variability in marine isotope stage 5 and termination II, Paleoceanography, 16, 280-292, 2001.

Oppo, D. W., McManus, J. F., and Cullen, J. L.: Evolution and demise of the Last Interglacial warmth in the subpolar North Atlantic, Quat. Sci. Rev., 25, 3268-3277, 2006.

Pelejero, C., Grimalt, J. O., Sarnthein, M., Wang, L., and Flores, J.A.: Molecular biomarker record of sea surface temperature and climatic change in the South China Sea during the last 140000 years, Mar. Geol., 156, 109-121, 1999.

Peterson, R. G. and Stramma, L.: Upper-level circulation in the South Atlantic Ocean, Progr. Oceanogr. 26, 1-73, 1991.

Peterson, L. C., Haug, G. H., Hughen, K. A., and Rohl, U.: Rapid Changes in the Hydrologic Cycle of the Tropical Atlantic During the Last Glacial, Science, 290, 1947-1951, 2000.

Prell, W. L. and Damuth, J. E.: The climate-related diachronous disappearance of Pulleniatina obliquiloculata in late quaternary sediments of the Atlantic and Caribbean, Mar. Micropaleontol. 3, 267-277, 1978.

Ramstorf, S.: Timing of abrupt climate change: A precise clock, Geophys. Res. Lett. 30, 1510, doi:10.1029/2003GL017115, 2003.

Reimer, P. J., Bard, E., Bayliss, A., Beck, J. W., Blackwell, P. G., Bronk Ramsey, C., Buck, C. E., Cheng, H., Edwards, R. L., Friedrich, M., Grootes, P. M., Guilderson, T. P., Haflidason, H., Hajdas, I., Hatté, C., Heaton, T. J., Hoffmann, D. L., Hogg, A. G., Hughen, K. A., Kaiser, K. F., Kromer, B., Manning, S. W., Niu, M., Reimer, R. W., Richards, D. A., Scott, E. M., Southon, J. R., Staff, R. A., Turney, C. S. M., and van der Plicht, J.: IntCal13 and Marine13 Radiocarbon Age Calibration Curves 0-50 000 Years cal BP, Radiocarbon, 55, 1869-1887, 2013.

Reynolds, R. W., Rayner, N. A., Smith, T. M., Stokes, D. C., and Wang, W.: An Improved In Situ and Satellite SST Analysis for Climate, J. Climate, 15, 1609-1625, 2002.

Ritz, S.P. Stocker, T. F., Grimalt, J. O., Menviel, L., and Timmermann, A.: Estimated strength of the Atlantic overturning circulation during the last deglaciation, Nat. Geosci., 6, 208-212, 2013.

Robinson, L. F., Adkins, J. F., Keigwin, L. D., Southon, J., Fernandez, D. P., Wang, S.-L., and Scheirer, D. S.: Radiocarbon variability in the western north Atlantic during the last deglaciation, Science, 310, 1469-1473, 2005.

Rühlemann, C., Diekmann, B., Mulitza, S., and Frank, M.: Late Quaternary changes of western equatorial Atlantic surface circulation and Amazon lowland climate recorded in Ceará Rice deep-sea sediments, Paleoceanography, 16, 293-305, 2001.

Saliot, A., Mejanelle, L., Scribe, P., Fillaux, J., Pepe, C., Jabaud, A., and Dagaut, J.: Particulate organic carbon, sterols, fatty acids and pigments in the Amazon River system, Biogeochemistry, 53, 79-103, 2001.

Schmidt, M. W., Spero, H. J., and Lea, D. W.: Links between salinity variation in the Caribbean and North Atlantic thermohaline circulation, Nature, 428, 160-163, 2004.

Schneider, R. R, Müller, P. J., Ruhland, G., Meinecke, G., Schmidt, H., and Wefer, G.: Late Quarternary surface temperatures and productivity in the east-equatorial South Atlantic: response to changes in trade/monsoon wind forcing and surface water advec- tion, in: The South Atlantic: Present and Past Circulation, edited by: Wefer, G., Berger, W. H., Siedler, G., and Webb, D., Springer, Berlin, Heidelberg, 527-551, 1996.

Schneider, R. R, Müller, P. J., and Acheson, R: Atlantic alkenone sea-surface temperature records: Low versus mid latitudes and differences between hemispheres, in: Reconstructing Ocean History: A Window into the Future, edited by: Abrantes, F. and Mix, A. C., Proc. 6th Internat. Conf. On Paleoceanography, August 1998, Lisbon, Kluwer Academic/Plenum Publishers, New York, 33-55, 1999.

Seager, R. and Battisti, D. S.: Challenges to our understanding of the general circulation: abrupt climate change, in: Global circulation of the atmosphere, edited by: Schneider, T. and Sobel, S., Princenton University Press, 331-337, 2007.

Shackleton, N. J., Hall, M. A., and Vincent, E.: Phase relationships between millennial-scale events $64000-24000$ years ago, Paleoceanography, 15, 565-569, 2000.

Shipboard Scientific Party: Shipboard Scientific Party MD132PICASSO, IMAGES XI Cruise Report, Institut Polaire Français Paul-Émile Victor (IPEV), OCE2004/02, 76 pp., doi:10013/epic.42897.d001, 2003.

Simon, M. H., Arthur, K. L., Hall, I. R., Peeters, F. J. C., Loveday, B. R., Barker, S., Ziegler, M., and Zahn R.: Millenial-scale Agulhas Current variability and its implications for salt-leakage through the Indian-Atlantic Ocean Gateway, Earth Planet. Sci. Lett., 383, 101-112, 2013.

Stern, J. V. and Lisiecki, L. E.: Termination 1 timing in radiocarbondated regional benthic $\delta^{18} \mathrm{O}$ stacks, Paleoceanography, 29, 11271142, 2014.

Stocker, T. F.: The Seesaw Effect, Science, 282, 61-62, 1998.

Stocker, T. F. and Johnsen, S. J.: A minimum thermodynamic model for the seesaw, Paleoceanography, 18, PA1087, doi:10.1029/2003pa000920, 2003.

Stocker, T. F. and Johnsen, S. J.: Correction to "A minimum thermodynamic model for the bipolar seesaw", Paleoceanography, 20, PA1002, doi:10.1029/2004PA001108, 2005.

Stocker, T. F. and Marchal, O.: Abrupt climate change in the computer: Is it real?, P. Natl. Acad. Sci. USA, 97, 1362-1365, 2000.

Stramma, L. and Schott, F.: The mean flow field of the tropical Atlantic Ocean, Deep-Sea Res. Pt. II, 46, 279-303, 1999.

Svendsen, J. I., Alexanderson, H., Astakhov, V. I., Demidov, I., Dowdeswell, J. A., Funder, S., Gataullin, V., Henriksen, M., Hjort, C., Houmark-Nielsen, M., Hubberten, H. W., Ingolfsson, O., Jakobsson, M., Kjær, K. H., Larsen, E., Lokrantz, H., Lunkka, J. P., Lyså, A., Mangerud, J., Matiouchkov, A., Murray, A., Möller, P., Niessen, F., Nikolskaya, O., Polyak, L., Saarnisto, M., Siegert, C., Siegert, M. J., Spielhagen, R. F., Stein, R.: Late Quaternary ice sheet history of northern Eurasia, Quat. Sci. Rev., 23, 1229-1271, 2004.

Teller, J. T., Leverington, D. W., and Mann, J. D.: Freshwater outbursts to the oceans from glacial Lake Agassiz and their role in climate change during the last deglaciation, Quat. Sci. Rev. 21, 879-887, 2002.

Thompson, L. G., Davis, M. E., Mosley-Thompson, E., Sowers, T. A., Henderson, K. A., Zagorodnov, V. S., Lin, P.-N., Mikhalenko, V. N., Campen, R. K., Bolzan, J. F., Cole-Dai, J., and Francou, B.: A 25000 -Year Tropical Climate History from Bolivian Ice Cores, Science, 282, 1858-1864, 1998. 
Trenberth, K. E. and Caron, J. M.: Estimates of Meridional Atmosphere and Ocean Heat Transports, J. Clim., 14, 3433-3443, 2001.

Tzedakis, P. C., McManus, J. F., Hooghiemstra, H., Oppo, D. W., and Wijmstra, T. A.: Comparison of changes in vegetation in northeast Greece with records of climate variability on orbital and suborbital frequencies over the last 450000 years, Earth Planet. Sci. Lett., 212, 197-212, 2003.

Vicalvi, M. A.: Zoneamento bioestratigráfico e paleoclimático do quaternário superior do talude da Bacia de Campos e platô de São Paulo adjacente, com base em foraminíferos planctônicos, Anu. Inst. Geocienc, 22, 117-119, 1999.

Villanueva, J. and Grimalt, J. O.: Gas Chromatographic Tuning of the Uk'37 Paleothermometer, Anal. Chem., 69, 3329-3332, 1997.

Villanueva, J., Pelejero, C., and Grimalt, J. O.: Clean-up procedures for the unbiased estimation of $\mathrm{C} 37$ alkenone sea surface temperatures and terrigenous n-alkane inputs in paleoceanography, J. Chromatogr. A, 757, 145-151, 1997.

Wang, Y. J., Cheng, H., Edwards, R. L., An, Z. S., Wu, J. Y., Shen, C.-C., and Dorale, J. A.: A High-Resolution Absolute-Dated Late Pleistocene Monsoon Record from Hulu Cave, China, Science, 294, 2345-2348, 2001.

Wang, X., Auler, A. S., Edwards, R. L., Cheng, H., Cristalli, P. S., Smart, P. L., Richards, D. A., and Shen, C. C.: Wet periods in northeastern Brazil over the past $210 \mathrm{kyr}$ linked to distant climate anomalies, Nature, 432, 740-743, 2004.
Weaver, A. J., Saenko, O. A., Clark, P. U., and Mitrovica, J. X.: Meltwater Pulse 1A from Antarctica as a Trigger of the BøllingAllerød Warm Interval, Science, 299, 1709-1713, 2003.

Weijer, W., De Ruijter, W. P. M., Sterl, A., and Drijfhout, S. S.: Response of the Atlantic overturning circulation to South Atlantic sources of buoyancy, Global Planet. Change, 34, 293-311, 2002.

Weldeab, S., Schneider, R. R., and Kölling, M.: Deglacial sea surface temperature and salinity increase in the western tropical Atlantic in synchrony with high latitude climate instabilities, Earth Planet. Sc. Lett., 241, 699-706, 2006.

Wolff, E. W., Chappellaz, J., Blunier, T., Rasmussen, S. O., and Svensson, A.: Millennial-scale variability during the last glacial: The ice core record, Quat. Sci. Rev., 29, 2828-2838, 2010.

Zabel, M., Wagner, T., and DeMenocal, P.: Terrigenous Signals in Sediments of the Low-Latitude Atlantic - Indications to Environmental Variations during the Late Quaternary: Part II: Lithogenic Matter, Book Chapter, 2003. 1-23, 2003.

Zarriess, M., Johnstone, H., Prange, M., Steph, S., Groeneveld, J., Mulitza, S., and Mackensen, A.: Bipolar seesaw in the northeastern tropical Atlantic during Heinrich stadials, Geophys. Res. Lett., 38, L04706, doi:10.1029/2010gl046070, 2011. 